\title{
CHRONOMETRICKÝ VÝSKUM MURÍV KOSTOLA SV. JURAJA V KOSTOLANOCH POD TRIBEČOM ${ }^{1}$
}

\author{
PETER BARTA - MARTIN BÓNA - MARIÁN KELEŠI
}

\begin{abstract}
Abstrakt: Príspevok referuje o výsledkoch najnovšieho výskumného projektu zameraného na ${ }^{14}$ C datovanie vzoriek odobratých z predrománskych konštrukcii kostola a nadväzuje tak na prvé výsledky chronometrického výskumu primárneho dreveného prvku stavby, uverejnené v roku 2010. Výsledky novšich ${ }^{14} \mathrm{C}$ meraní spresnili obdobie vzniku murovanej stavby a prispeli tak $k$ poznaniu stavebných dejín jednej $z$ najstaršich ucelene stojacich architektúr na územi Slovenska.
\end{abstract}

Kl'účové slová: chronometrický výskum $-{ }^{14}$ C datovanie - predrománska architektúra - sakrálna architektúra.

\section{Chronometric Research of Masonry of St. George's Church in Kostol'any pod Tribečom}

Abstract: This paper sums up results of the most recent project focused on ${ }^{14} \mathrm{C}$ dating of samples from pre-Roman phases of St. George's. The project has been triggered by the outcomes of initial chronometric research of a primary timber published in 2010. $\mathrm{New}{ }^{14} \mathrm{C}$ dates narrow the date for construction of the masoned church, which in Slovakia presents one of the earliest buildings preserved in its entirety.

Key words: chronometric research - radiocarbon dating - pre-Romanesque architecture - religious architecture

\section{Poloha a význam pamiatky}

Sakrálna stavba dominuje na východnom vyvýšenom okraji obce, situovanej v údolí potoka Drevenica v južnom pásme Tribečského pohoria. Pozostáva z pozdížneho jednolodia s vežou a kvadratického presbytéria, orientovaného na juhovýchod. Najstaršia predrománska čast' je situovaná vo východnej polovici stavby a pozostáva $\mathrm{z}$ valene klenutého presbytéria a malého jednolodia. Na predrománsku lod' sa od západu napája širšia neskororománska čast' lode s emporou a vežou, pričom celok na západe ukončuje novodobá prístavba lode zo 60. rokov 20. storočia.

Do polovice 20. storočia objekt nevzbudzoval pozornost' odborníkov a kvôli havarijnému stavu bol dlhodobejšie uzavretý. Zmena nastala v roku 1960, ked' sa zist’ovacou sondážou pracovníkov SÚPSOP odkryli v interiéri stredoveké nástenné mal'by (Dvořáková-Krása 1961, 197-201), čo priviedlo pamiatkarov k iniciatíve za záchranu a preskúmanie kostola. Následne sa v rokoch 1964-1965 uskutočnil prvý interdisciplinárny výskum, vd’aka ktorého výsledkom sa pamiatka zaradila medzi najstaršie ucelene zachované stavby na území Slovenska.

\section{Doterajšie poznatky o datovaní a vývoji predrománskej časti kostola}

Prelomové poznatky priniesol archeologický výskum AÚ SAV v Nitre vedený A. Habovštiakom $(1965 ; 1966 ; 1968 ; 1978)$, ktorý okrem objasnenia dispozičného vývoja pamiatky priniesol aj doklady o vzniku jej najstaršej časti pred polovicou 11. storočia. Spoločne s umelecko-historickým výskumom L. Šáškyho $(1965 ; 1968)$ určili ako najstaršiu predrománsku čast' kostola malé jednolodie (vnútro 5,2×3,6 m) s kvadratickým presbytériom $(3,4 \times 2,1-2,3 \mathrm{~m})$, pričom neskoršie rozšírenie lode na západ stanovili do neskororománskeho obdobia okolo polovice 13. storočia. V rámci výskumov sa tiež upresnil názor na datovanie odkrytých najstarších nástenných malieb (porovnaj Dvořáková-Krása 1961, 199; Krása 1968, 124), ktoré väčšina bádatel’ov zaradila k pôvodnej súčasti predrománskeho kostola z polovice 11. storočia (Fodor 1968, 102; Bakoš 1968, 181). V takomto duchu zotrvalo ich hodnotenie v domácej spisbe do dnešných dní (Gerát 2007, 32-34; Maříková-Kubková-Berger 2009, 148; Kresánek 2009, 326; Maříko-

1 Túto štúdiu autori venujú ctenej a váženej pani kolegyni Mgr. Silvii Paulusovej pri príležitosti jej životného jubilea. 


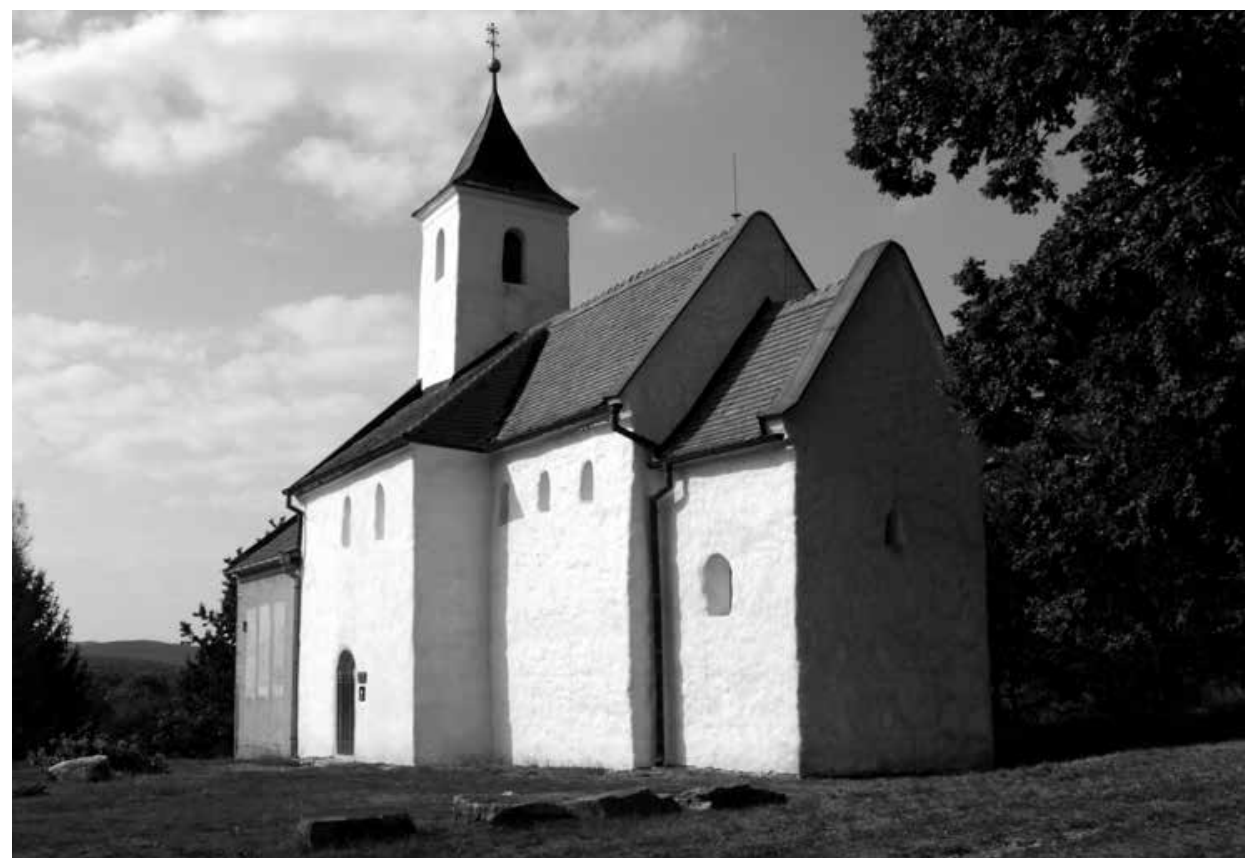

Obr. 1. Celkový pohlad na kostol od juhovýchodu. Foto M. Bóna, 2012 Abb. 1. Gesamtansicht der Kirche von Südosten. Foto M. Bóna, 2012.

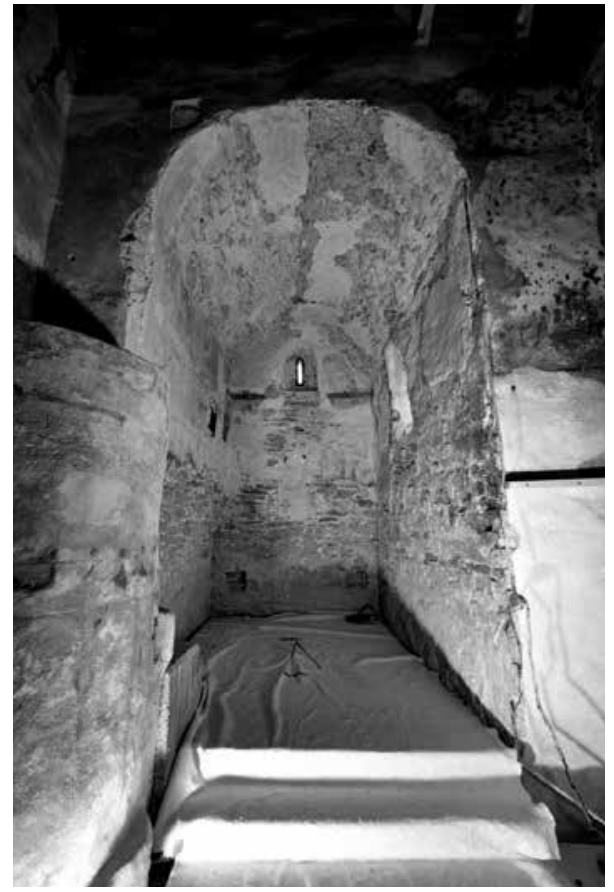

Obr. 2. Celkový pohl’ad do presbytéria. Foto M. Keleši, 2012. Abb. 2. Gesamtansicht des Chorraums. Foto M. Keleši, 2012.

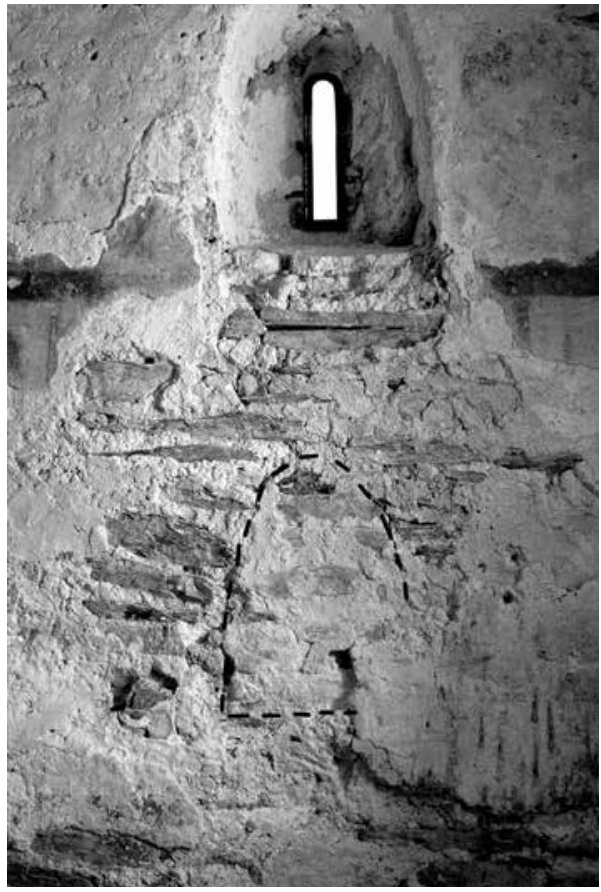

Obr. 3. Nález zamurovaného otvoru vo východnej časti presbytéria. Foto M. Keleši, 2012.

Abb. 3. Fund einer zugemauerten Öffnung im Ostteil des Chorraums. Foto M. Keleši, 2012. 
vá-Kubková 2011, 91; Baxa-Maříková-Kubková 2013, 197-200), i ked’ revízny umelecko-historický a architektonicko-historický výskum M. Bónu v rokoch 2000-2001 a 2009-2010 odkryl situácie, ktoré primárnost' malieb spochybňovali (Bóna 2010, 45, 128; 2012, 82; 2014, 149-150).

Posun v datovaní najstaršej časti kostola do začiatku 11. storočia priniesol revízny archeologický výskum v exteriéri v rokoch 2006-2007 (Baxa-Bisták 2009, 61) a následný archeologický objav neznámych kolových jamiek v interiéri v roku 2010 priviedol výskumníkov k záverom, že sú dokladom o existencii dreveného predchodcu kamenného kostola (Baxa-Maříková-Kubková 2010; 2011; 2013, 195-196).

V roku 2009 boli vyhodnotené a verejne prezentované aj prvé výsledky chronometrického výskumu, zameraného na datovanie muriva predrománskej stavby prostredníctvom primárneho stavebného dreva. Išlo o dubovú polgul'atinovú konzolu lešenia z južnej fasády lode, odobratú už pri výskume fasád v roku 2001 (vzorka KPT_1). Tento drevený stavebný prvok svojou stratigrafickou polohou v predrománskom murive preukazne patril k prvkom zabudovaným do muriva počas výstavby predrománskeho kostola. Absencia stôp po invázii drevokazného hmyzu a spôsob povrchového opracovania, i samotný účel konštrukčného prvku vylučovali možnost', že sa jedná o druhotne použitý stavebný materiál z inej staršej stavby a predurčovali ho na chronometrické datovanie výstavby predrománskeho kostola.

V roku 2009 bola lešenárska konzola KPT_1 skúmaná dendrochronologicky, avšak bez synchronizácie, ktorá by sa dala interpretovat' ako absolútno-chronologický výsledok; na vtedy skúmanom transverzálnom reze bolo 37 meratel'ných letokruhov (Barta-Bóna 2010). Následne bola vzorka datovaná rádiouhlíkom (AMS). Konvenčný ${ }^{14} \mathrm{C}$ vek nameraný na sekvencii piatich letokruhov bol kalibrovaný a výsledná hodnota vypočítaná pre výrub stromu sa nachádzala v intervale 703-915 calAD. Tento výsledok sa stal indíciou, ktorá upozornila na možnost' staršieho datovania predrománskej stavby, a to najneskôr do začiatku 10. storočia (bližšie: Barta-Bóna 2010, 58).

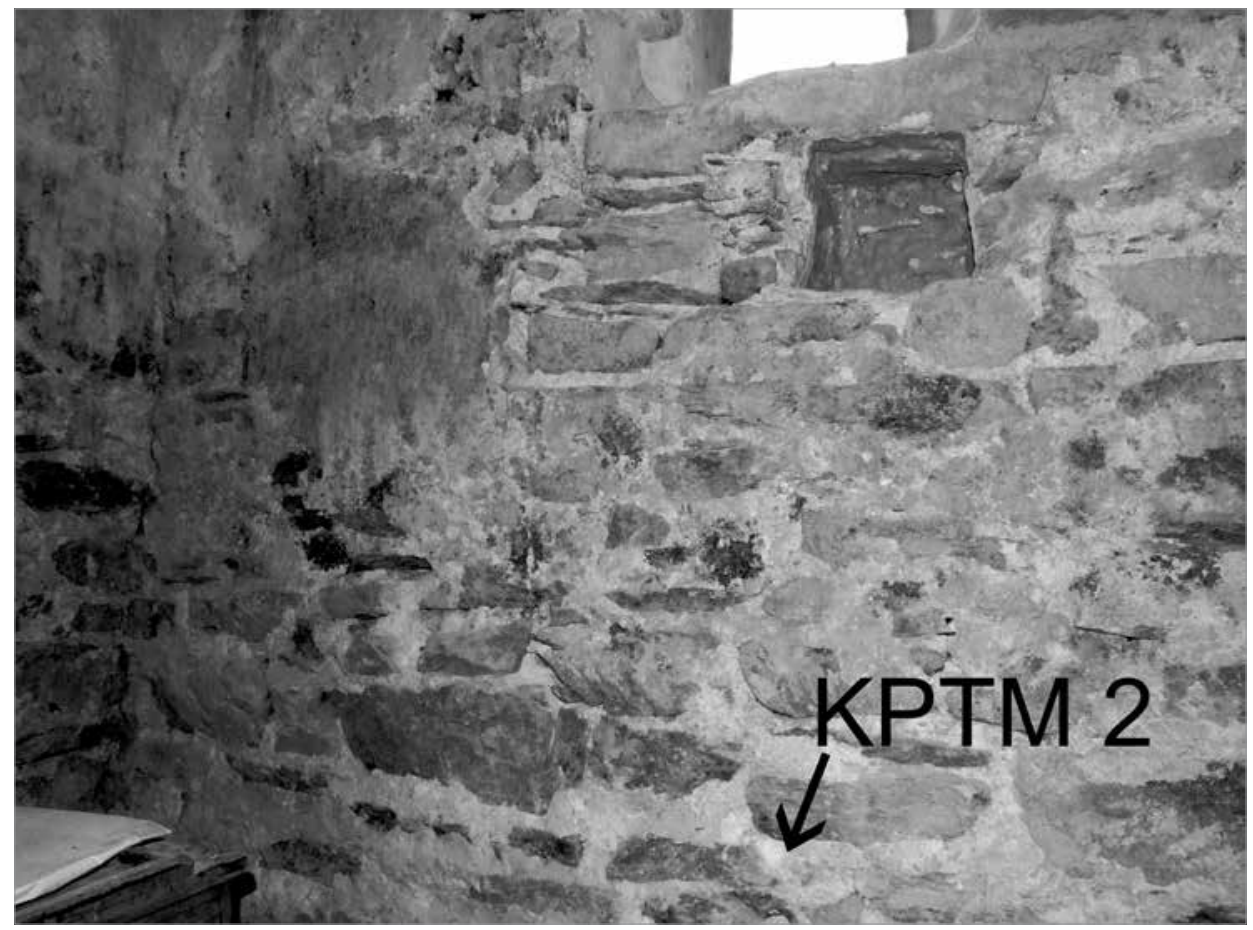

Obr. 4. Štruktúra muriva v južnej stene presbytéria s miestom odberu vzorky. Foto M. Bóna, 2014.

Abb. 4. Struktur des Mauerwerks der Südwand des Chorraums mit Stelle, an der die Probe entnommen wurde. Foto M. Bóna, 2014. 


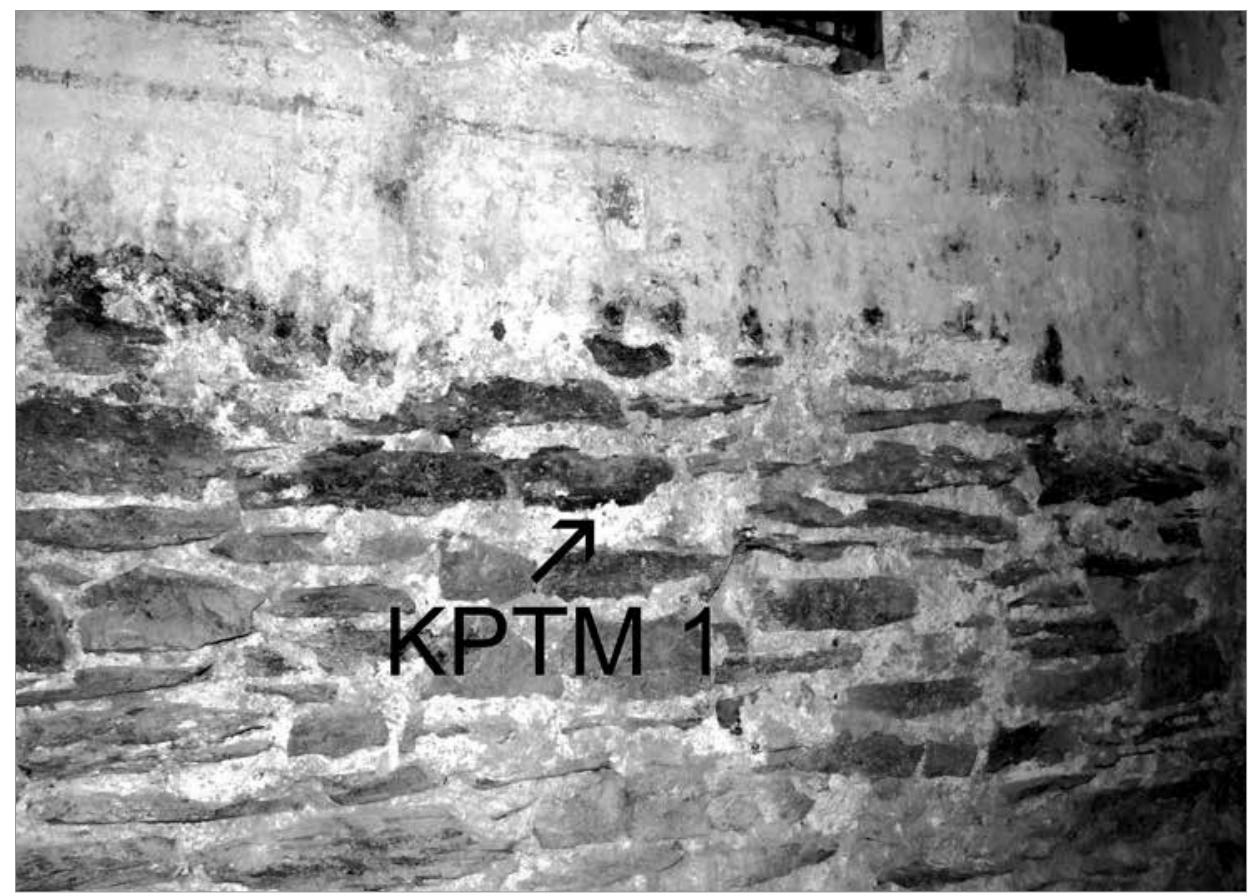

Obr. 5. Štruktúra muriva severnej steny presbytéria s miestom odberu vzorky. Foto M. Bóna, 2014.

Abb. 5. Struktur des Mauerwerks der Nordwand des Chorraums mit Stelle, an der die Probe entnommen wurde. Foto M. Bóna, 2014.

\section{Chronometrický výskum kostola v rokoch 2010-2014}

Výsledok prvého ${ }^{14} \mathrm{C}$ merania lešenárskej konzoly KPT_1 (Barta-Bóna 2010) podnietil chronometrický výskum d’alších vzoriek dreva, omietok a malty. Ciel'om nášho úsilia bolo datovat' výstavbu najstaršej fázy predrománskeho kostola. Z dôvodu vzájomnej kontroly dát sme vyberali také vzorky, ktoré majú k dobe výstavby kostola kvalitatívne odlišný vzt'ah a ktorých mechanizmus vzniku je rozdielny (pozri k metóde: Barta 2008; 2008a). Spolu bolo na dvoch prvkoch stavebného dreva, troch vzorkách vápennej omietky a jednej vzorke uhlíka v omietke nameraných $15{ }^{14} \mathrm{C}$ dát, $\mathrm{z}$ ktorých 10 prezentujeme v predkladanom príspevku.

Pre datovanie najstaršej predrománskej etapy sme teda použili vzorky, ktoré majú rozdielny časový vzt’ah k dobe výstavby kostola. Ako nositela terminu post quem pre výstavbu sme vybrali zvyšok palivového dreva z najstaršej primárnej omietky, nositel'mi terminu a quo boli vzorky mált a omietok, ako aj lešenárska konzola KPT_1. Z hl’adiska vzniku signálu ide o dve skupiny vzoriek. Omietka a malta na líci murív predstavujú vzorky technolitu - antropogénneho kalcitu s rapídne absorbovaným atmosférickým $\mathrm{CO}_{2}$; vzorky dreva sú vzorkami $\mathrm{C}_{3}$ biómu, v ktorých signál vznikal v priebehu niekol'kých rokov, v prípade analyzovaných sekvencií odobratých z lešenárskej konzoly ide o 5 a 10 rokov.

\section{Doba výrubu stromu pre lešenársku konzolu KPT_1 na južnej fasáde lode}

Po prvom ${ }^{14} \mathrm{C}$ meraní vzorky z lešenárskej konzoly KPT_1 sme ju v roku 2010 skúmali detailnejšie (Barta-Bóna 2011). Na novoodobratom transverzálnom reze sme zistili 42 meratel'ných letokruhov. $Z$ tohto letokruhového radu sme na troch miestach odobrali desat'ročné sekvencie dreva, a to letokruhy $1-10,21-30$ a 31-40. Najmladšie dva letokruhy $(41,42)$, ktoré sa zachovali len na malom úseku obvodu tejto časti prvku, sme nevzorkovali. 
Meraním dekadických vzoriek sme získali tri d’alšie ${ }^{14} \mathrm{C}$ dáta (AMS), ktoré sme spolu s meraním z roku 2009 (tab. 1) použili pre zist'ovanie najneskoršieho možného dátumu pre výrub stromu, z ktorého vyrobili lešenársku konzolu KPT_1. Riadenou kalibráciou ${ }^{14} \mathrm{C}$ dát v programe OxCal 4.2 (Bronk Ramsey 2009; D_Sequence, Bronk Ramsey et al. 2001) sme sa snažili zúžit' rozsah kalendárneho veku, ktorého generovanie je v 9. storočí výrazne ovplyvnené priebehom kalibračnej krivky (plateau, obr. 6, tab. 1).

\begin{tabular}{|c|c|c|c|c|}
\hline Vzorka & Letokruhy & Lab. kód & $\begin{array}{c}\text { Konvenčný }{ }^{14} \text { C vek } \\
\text { BP, 1 sigma }\end{array}$ & $\begin{array}{c}\text { Kalendárny dátum calAD } \\
(95,4 \%)\end{array}$ \\
\hline KPT_1_1 & $1-10$ & BETA293307 & $1180 \pm 30$ & $\begin{array}{c}730-736(0,7 \%) \\
769-901(87,5 \%) \\
921-951(7,2 \%)\end{array}$ \\
\hline KPT_1_3 & $21-30$ & BETA291858 & $1140 \pm 30$ & $\begin{array}{c}777-793(5,5 \%) \\
802-848(11,3 \%) \\
855-981(78,6 \%)\end{array}$ \\
\hline KPT_1_2009 & $31-35$ & BETA266406 & $1210 \pm 40$ & $\begin{array}{c}687-895(93,7 \%) \\
928-940(1,7 \%)\end{array}$ \\
\hline KPT_1_4 & $31-40$ & BETA291859 & $1200 \pm 30$ & $715-744(6,2 \%)$ \\
& & & & $765-895(87,8 \%)$ \\
\end{tabular}

Tab. 1. ${ }^{14} \mathrm{C}$ dáta namerané na vzorkách z lešenárskej konzoly KPT_1. Kalendárne dáta sú výsledkom kalibrácie s nulovou apriórnou informáciou.

Tab. 1. An den Proben von der Gerüstkonsole KPT_1 gemessene ${ }^{14}$ C-Daten. Die Kalenderdaten sind das Ergebnis einer Kalibrierung mit Null-A-priori-Information.

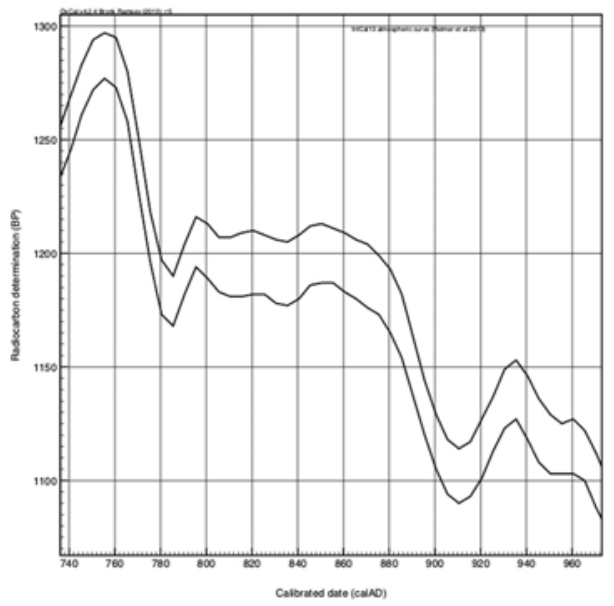

Obr. 6. Plateau kalibračnej krivky IntCal13 v 9. storočí calAD. Abb. 6. Plateau der Kalibrierungskurve IntCal13 im 9. Jhdt. calAD.

Pre datovanie výrubu stromu pre KPT_1 je nevyhnutné zaoberat' sa počtom letokruhov nedatovaných rádiouhlíkom, ktoré oddel'ujú dobu rastu najmladšieho datovaného pletiva od doby výrubu stromu. Po prvé, ide o počet zachovaných, ale nevzorkovaných letokruhov jadrového dreva, d’alej počet letokruhov jadrového dreva, ktoré sa na vzorke prípadne nezachovali vôbec, a napokon počet letokruhov bel'ového dreva, pre ktorý existuje štatistický odhad. Pre zistenie dátumu výrubu je k hornej hranici intervalu najmladšej vzorky (KPT_1_4, letokruhy 31-40) potrebné pripočitat' súčet letokruhov troch uvedených kategórií.

Jasne kvantifikovatel'ný je počet zachovaných, ale nevzorkovaných letokruhov jadrového dreva na transverzálnom reze $\mathrm{z}$ roku 2010, ktoré sú dva. Druhou jasnou kvantitou je počet chýbajúcich letokruhov bel'ového dreva, ktorý závisí od veku jedinca. Predpokladaný vek stromu, z ktorého KPT_1 vyrobili, je okolo 50 rokov, čo je hraničnou hodnotou pre dve kategórie počtu letokruhov bel'ového dreva pre dub (Heussner 1999). Ked’že ciel’om nášho výskumu bolo zistit' najneskorší možný dátum výrubu, našu vzorku sme zaradili do kategórie pät'desiat- až storočných jedincov a pre výpočet sme zvolili maximum počtu letokruhov bel'u v tejto kategórii,t. j. 30 rokov (Heussner 1999). Posledná kvantita, ktorú je potrebné zvážit', je počet letokruhov prípadne chýbajúceho jadrového dreva. Na prvku sa síce nezachovalo bel'ové drevo, ale jeho zaoblený povrch indikuje, že bel' bol odstránený krátko po vyt’atí stromu. Zaoblený povrch je preto možné považovat' za hranicu jadrového a bel'ového dreva a počet chýbajúcich letokruhov jadrového dreva na transverzálnom reze z roku 2010 je možné považovat' za blízky nule alebo nulový. 


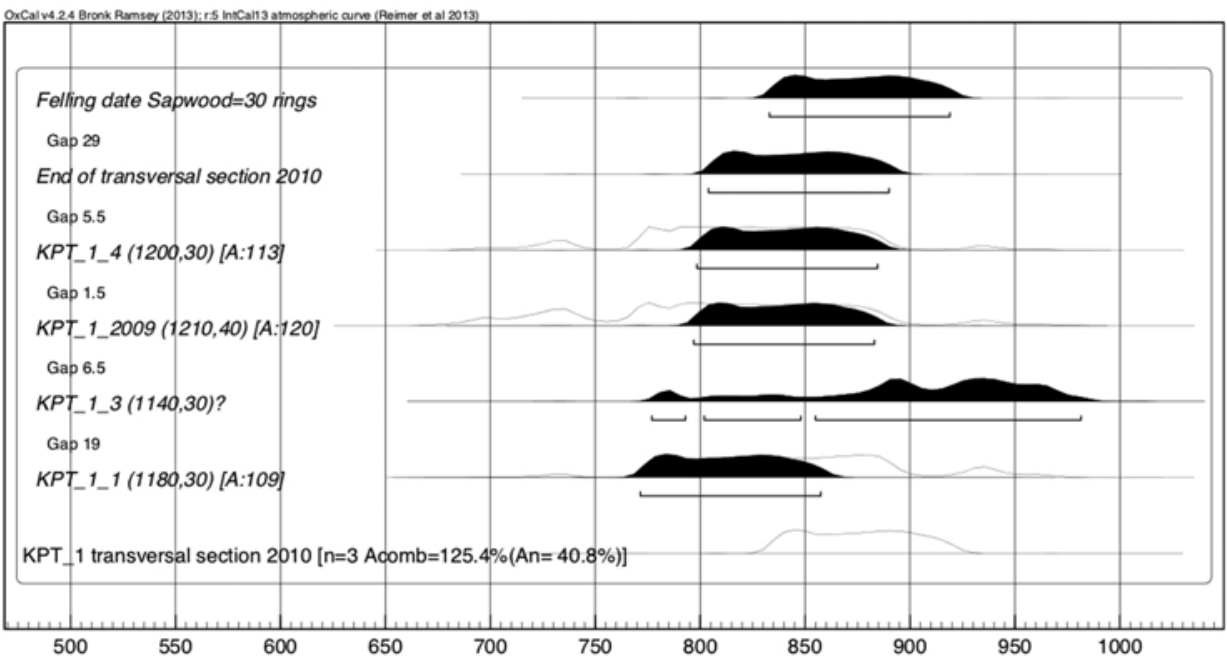

Obr. 7. Datovanie najneskoršieho možného dátumu pre výrub stromu pre lešenársku konzolu KPT_1. Kalibrácia ${ }^{14} \mathrm{C}$ dát zohl'adňuje pozíciu jednotlivých vzoriek dreva v rámci kmeňa. Dátum výrubu je vypočítaný pre hodnotu maximálneho počtu bel’vého dreva (30; Heussner 1999), počet na vzorke nezachovaných letokruhov jadrového dreva je považovaný za nulový. Najneskorší možný dátum výrubu je rok 919 calAD. Vyznačené sú intervaly pre konfidenčnú hladinu $95,4 \%$.

Abb. 7. Datierung des spätmöglichsten Fälldatums des Baums der Gerüstkonsole KPT_1. Die Kalibrierung der ${ }^{14} \mathrm{C}-D a t e n$ berücksichtigt die Lage der einzelnen Holzproben im Innern des Stamms. Das Fälldatum wird für den Wert der maximalen Anzahl an Splintholzjahrringen berechnet (30; Heussner 1999), die Anzahl der nicht erhaltenen Jahrringe des Kernholzes wird als Null angesehen. Das spätmöglichste Fälldatum ist das Jahr 919 calAD. Die Intervalle sind mit einem Konfidenzniveau von 95,4\% gekennzeichnet.

Na základe vyššie uvedených apriórnych informácií sme ${ }^{14} \mathrm{C}$ dáta kalibrovali (obr. 7) s použitím kalibračnej krivky IntCal13 (Reimer et al. 2013). Ukázalo sa, že konvenčný ${ }^{14} \mathrm{C}$ vek pre letokruhy 21-30 (KPT_1_3) nerešpektuje vzt’ahy medzi vzorkami v reálnom čase, a preto nebol do výpočtu zaradený.

Riadená kalibrácia ${ }^{14} \mathrm{C}$ dát priniesla výsledok, že na konfidenčnej hladine $95,4 \%$ je najneskoršia možná alternatíva výrubu stromu pre KPT_1 rok 919 calAD (obr. 7). Použitie tohto absolútneho datovania ako najneskoršieho možného terminu a quo pre výstavbu najstaršieho predrománskeho kostola je priamo závislé od doby, ktorá uplynula medzi výrubom stromu a zabudovaním dreveného prvku do muriva stavby. Preto je potrebné vyjadrit' sa k možnosti, že analyzovaný prvok predstavuje sekundárne použité stavebné drevo zo staršej drevenej stavby.

\section{Diskusia k možnosti sekundárneho použitia polgul’atiny pre lešenársku konzolu KPT_1}

Dubová polgul'atina KPT_1 bez stôp po rozsušení pred vložením do muriva má prevažne oblý povrch, čo indikuje, že belové drevo bolo odstránené za čerstva. Osekanie na obvode kmeňa je najzretel'nejšie v mieste, kde z kmeňa vyrastal konár. Na povrchu polgul'atiny nie sú stopy činnosti drevokazného hmyzu a na transverzálnom reze z roku 2010 je prítomná infestácia v mizivom rozsahu (3 požerky). Tento stav nasvedčuje tomu, že konštrukčný prvok bol vložený do muriva krátko po výrube stromu a povrch prvku nebol vol’ne prístupný drevokaznej biote.

Uvedené zistenia nepodporujú publikovaný názor P. Baxu a J. Maříkovej-Kubkovej, že stavebné drevo môže pochádzat’ z nejakej staršej drevenej stavby, napríklad dreveného kostola, ktorého existenciu tu predpokladajú na základe nálezu kolových jamiek ${ }^{2}$ (pričom najstarší ka-

2 V roku 2010 došlo pri archeologickom výskume interiéru predrománskeho kostola k objavu neznámych kolových jamiek i k revíznemu odkryvu jamiek zistených už počas archeologického výskumu v rokoch 1964-1965. Kým nález z rokov 1964-1965 bol autorom výskumu interpretovaný ako zvyšok konštrukcie lešenia z doby výstavby predrománskeho kamenného kostola alebo z doby jeho neskoršej prestavby (Habovštiak 1966 odbor. denník, 21-23;1968, 61; 1985, 189), autori revízneho výskumu jamky interpretujú ako doklad existencie dreveného predchodcu kamenného kostola (Baxa-Maříková-Kubková 2010; 2011; 2013, 195-196). Takáto interpretácia jamiek má ale z pohl’adu výsledkov architektonicko-historického výskumu z roku 2010 viacero protirečení a nebola jednotne prijatá ani archeológmi (Ruttkay 2011, 45). Na úrovni dnešných poznatkov sa javí pravdepodobnejšie pokladat' jamky za doklad pomocnej stavebnej konštrukcie z obdobia výstavby alebo neskoršej úpravy predrománskeho kamenného kostola (bližšie argumentácie Bóna 2014, 139-141). 
menný kostol datujú na začiatok 11. storočia, ked’že pre skoršie datovanie nemali k dispozícii archeologické argumenty; Baxa-Maříková-Kubková 2010, 159; 2013, 196-197, 215). Autormi pripúštané použitie staršej dubovej polgulatiny na konzolovo vystupujúci a staticky namáhaný prvok lešenia zo „stavebno-praktických dôvodov“ (Baxa-Maříková-Kubková 2013, 215) nepovažujeme za realistické, navyše na území s prirodzeným výskytom dubín. Podobne aj úvahu o zámernom použití staršieho stavebného dreva zo "symbolických dôvodov“ (Baxa-Maříková-Kubková 2013,215) považujeme za diskutabilnú. Väčšia čast’ prvku vystupujúca pred fasádu bola totiž po výstavbe kostola znehodnotená odpílením a zvyšok bol zatretý omietkou.

Priame argumenty, pre ktoré by bolo možné polgul'atinu považovat' za stavebný prvok zo staršej drevenej stavby, teda neexistujú. Výrub stavebného dreva a výrobu lešenárskej konzoly KPT_1 považujeme za súčast' stavebných aktivít bezprostredne súvisiacich s výstavbou kamenného kostola (Bóna 2014, 142 - pozn. 33). Dátum výrubu stromu pre KPT_1 je preto dátumom výstavby najstaršej etapy kostola, ktorého najneskoršou možnou alternatívou je rok 919 calAD (obr. 7).

\section{Datovanie fragmentu zuhol'nateného dreva KPTC_1 z hmoty omietky}

Drobný fragment zuhol’nateného dreva bol súčastou hmoty primárnej exteriérovej omietky, ktorá bola z okolia stredného okna na južnej fasáde lode odobratá v rámci analýzy stavebného materiálu počas architektonicko-historického výskumu v roku 2001. Fragment označený ako KPTC_1 (3 letokruhy, Quercus sp.) bol v roku 2012 vybratý pre datovanie s ciel'om získat' terminus post quem pre výstavbu najstaršej etapy predrománskeho kostola. Interpretujeme ho ako zvyšok palivového dreva použitého pri pálení vápna, ktorý sa do omietky dostal spolu s vápnom. Ked’že ide o zvyšok paliva, dátum na ňom nameraný musí predchádzat' dobe výstavby kostola. Vzhl'adom na to, že dub je dlhoveká drevina a nie je možné určit', z ktorej časti kmeňa analyzovaný fragment pochádza, obdobie rastu datovaných letokruhov môže predchádzat' dobe použitia dreva ako paliva aj o desiatky rokov. Nameraný ${ }^{14} \mathrm{C}$ dátum (AMS) teda datuje bližšie nešpecifikovanú dobu pred výstavbou kostola a slúži ako nepriamy argument pre datovanie najstaršieho predrománskeho kostola. Ciel’om takéhoto výberu vzorky bolo otestovat', či fragment uhlíka nemôže pochádzat' z 10. alebo 11. storočia, čo by vylučovalo dátum výstavby kostola indikovaný vzorkou KPT_1.

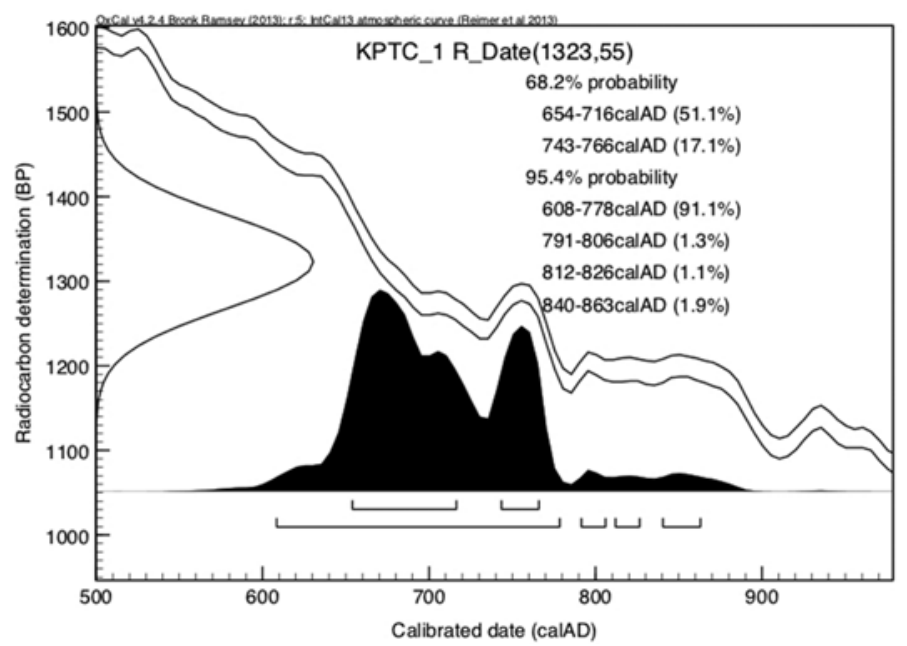

Obr. 8. Datovanie fragmentu zuhol'nateného dubového dreva KPTC_1 vypreparovaného z primárnej omietky z okolia stredného okna na južnej fasáde lode.

Abb. 8. Datierung des aus dem Primärputz im Bereich des Mittelfensters an der Südfassade des Kirchenschiffs präparierten, verkohlten Eichenholzfragments KPTC_1. 
Kalibrácia konvenčného ${ }^{14} \mathrm{C}$ veku (DSH4411: $1323 \pm 55 \mathrm{BP}$ ) priniesla výsledok, že tri letokruhy zuhol’nateného dreva z najstaršej primárnej omietky rástli v intervale 608-778 calAD alebo najneskôr medzi rokmi 791 a 863 calAD (obr. 8). Tento výsledok predstavuje nepriamy argument, že najstarší kamenný kostol mohol byt' postavený v dobe výrubu vzorky KPT_1.

\section{Datovanie kalcitu z exteriérovej omietky KPTM_3}

Datovaný $\mathrm{CaCO}_{3}$ je produktom reakcie $\mathrm{Ca}(\mathrm{OH})_{2}$ a atmosférického $\mathrm{CO}_{2}$, ktorá je základom tuhnutia vápenných stavebných hmôt. Kalcit extrahovaný zo vzoriek mált na líci murív a z omietok je tak nositel’om časového údaju o výstavbe vzorkovaných stavebných konštrukcií (Ringbom et al. 2014) v zmysle terminu a quo. Ako prvá bola odobratá vzorka omietky, ktorú označujeme ako KPTM_3, a to pôvodne z dôvodu analýzy stavebného materiálu počas architektonicko-historického výskumu v roku 2001. Ide o primárnu exteriérovú omietku z najstaršej predrománskej etapy v blízkosti západného okna na severnej fasáde lode kostola. V roku 2012 bola táto omietka zaradená medzi vzorky pre chronometrické datovanie Kostola sv. Juraja, v roku 2013 bol z nej vyseparovaný antropogénny kalcit a v roku 2014 boli na dvoch frakciách získaného $\mathrm{CO}_{2}$ namerané dve ${ }^{14} \mathrm{C}$ dáta (AMS).

$\mathrm{Z}$ viacerých frakcií $\mathrm{CO}_{2}$ je to práve prvá, ktorá predstavuje dátum tuhnutia vápennej zmesi; ciel’om merania viacerých frakcií je overit', či vyseparovaná vzorka kalcitu nie je kontaminovaná karbonátmi z geologických zdrojov s infinitným rádiouhlíkovým vekom (Folk-Valastro 1976, 207). Kalibrovaný rozsah konvenčného ${ }^{14} \mathrm{C}$ veku prvej frakcie (AAR18924,1:1209 $\pm 27 \mathrm{BP}$ ) by mohol znamenat', že dobu výstavby muriva treba hl'adat' v 9. storočí (obr. 9). Vzhl'adom na nižší konvenčný ${ }^{14} \mathrm{C}$ vek pre druhú frakciu je však táto vzorka stále predmetom výskumu a nameranú hodnotu pre prvú frakciu nie je zatial' možné použit' pre absolútno-chronologickú argumentáciu.

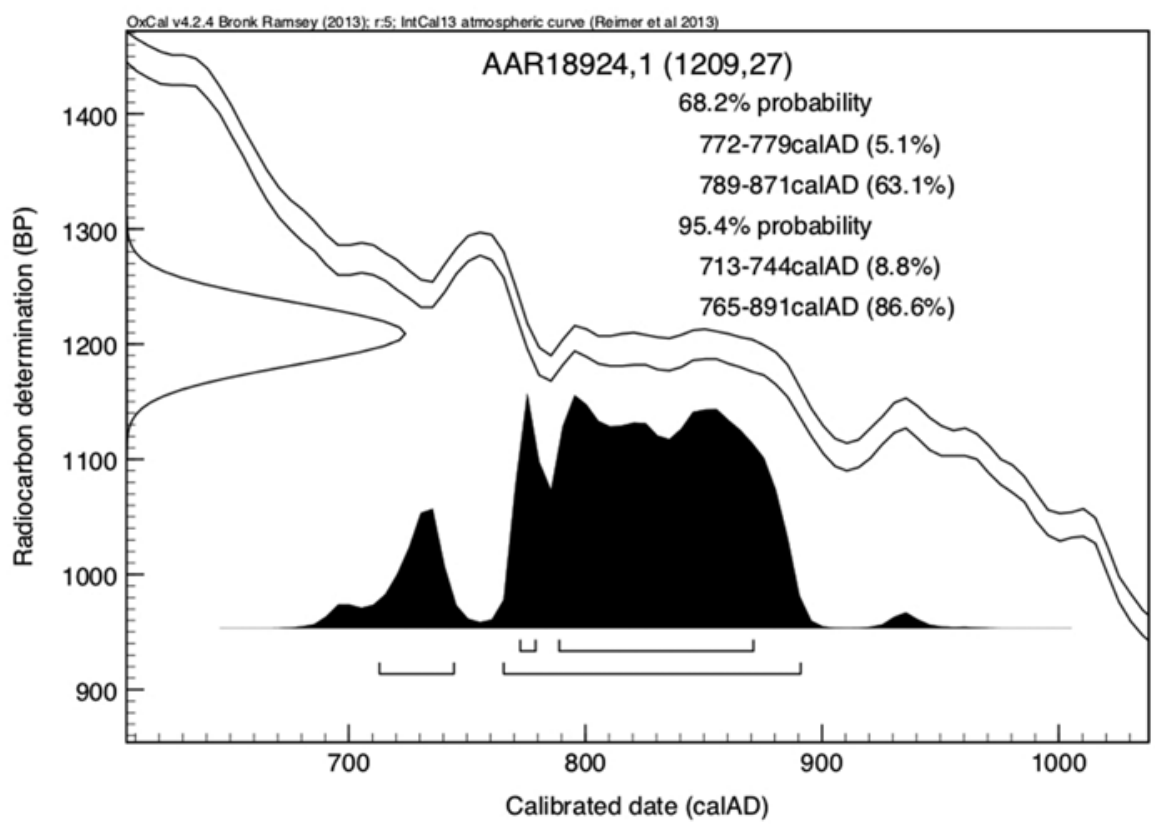

Obr. 9. Datovanie prvej frakcie $\mathrm{CO}_{2}$ vzorky KPTM_3.

Abb. 9. Datierung der ersten $\mathrm{CO}_{2}$-Fraktion der Probe KPTM_3. 


\section{Reštaurátorský výskum interiéru kostola od roku 2012}

V roku 2012 sa v interiéri kostola začal revízny reštaurátorský výskum ORA v Levoči pod vedením M. Kelešiho. Tento dodnes neukončený výskum je sprevádzaný očistovaním predrománskych malieb a stien od novodobých tmelov a omietok z čias obnovy interiéru v 60. rokoch 20. storočia, čím sa ponúkla jedinečná možnost' na revízne preskúmanie murív i historických omietkových vrstiev s výmal'bou. Doterajšie výsledky reštaurátorského výskumu doložili, že primárna povrchová úprava interiérových stien vznikla hrubším zat’ahovaním maltoviny nahadzovanej na vytlačenú maltu zo škár v procese postupného murovania kamenného muriva po vodorovných vrstvách. V styku vrstiev muriva sa tak na ploche stien prejavujú prekrývané plochy zat'ahovanej maltoviny, čím vznikol nahrubo zahládzaný povrch omietky. Omietka bola na viacerých miestach prichytávaná aj zatláčaním prstami murárov, ako to doložili nájdené odtlačky prstov. ${ }^{3}$ Rovnakú primárnu povrchovú úpravu s prekrývanými plochami omietky doložil aj architektonicko-historický výskum na fasádach v rokoch 2000-2001 (Bóna 2010, 82-83, 114-115). Týmito zisteniami sa zároveň vylúčila možnost' použitia doskového debnenia pri výstavbe kostola.

Ďalšími novými zisteniami reštaurátorského výskumu sa v zhode $\mathrm{s}$ predchádzajúcimi závermi umelecko-historického a architektonicko-historického výskumu v rokoch 2000-2001 a 2009-2010 (Bóna 2010, 127-128; 2012, 82; 2014, 149-150) definitívne potvrdil mladší pôvod predrománskej interiérovej výmal'by. Na severnej stene lode sa zistilo, že nanesenie omietky s maliarskou výzdobou bolo realizované na poškodenej primárnej povrchovej úprave stien. Ďalším dokladom bola zistená stratigrafia v okolí novoobjaveného otvoru na východnej stene presbytéria. Tento otvor neznámej funkcie (nika, okno ?) bol situovaný v strede steny pod dnešným oknom a jeho mladšia zamurovka bola prekrytá vyrovnávacou omietkou nesúcou vrchnú omietkovú vrstvu s predrománskou výmal'bou. Okrem toho reštaurátorský výskum objasnil aj postup realizácie maliarskeho programu v presbytériu a skorigoval staršie mylné interpretácie. ${ }^{4}$

\section{Datovanie kalcitu z interiérových omietok KPTM_1 a KPTM_2}

Nový reštaurátorský výskum znamenal možnost' odberu d’alších vzoriek. Naším cielom v januári 2013 bolo získat' omietku z najstaršej predrománskej etapy kostola. Ked’že primárna hmota kostola prešla už v raných dobách stavebnými úpravami, ${ }^{5}$ boli odobraté dve vzorky: zo severnej (KPTM_1) a južnej (KPTM_2) steny presbytéria, aby sme zvýšili pravdepodobnost', že aspoň jedna zo vzoriek bude odobratá z najstaršej úpravy stien.

Na základe dnešných poznatkov o stratigrafii omietok je možné povedat', že vzorka KPTM_2 z omietky na južnej stene presbytéria predstavuje primárnu ložnú prihadzovanú omietku súvisiacu so stavbou predrománskeho kostola. Hoci aj vzorka KPTM_1 z omietky severnej steny presbytéria bola odoberaná so zámerom vzorkovat' najstaršiu primárnu omietku, výsledky ${ }^{14} \mathrm{C}$ datovania $\mathrm{v}$ súlade $\mathrm{s}$ vyššie uvedeným reštaurátorským zistením naznačujú, že ju nie je možné stratigraficky jednoznačne charakterizovat'. Vzorka KPTM_1 môže reprezentovat': 1) mladšiu vysprávku najstaršej omietkovej vrstvy, 2) vyrovnávaciu omietku pod omietkou nesúcou predrománsku mal'bu alebo 3) samotnú predrománsku omietku nesúcu mal'bu.

Zo vzorky KPTM_1 bol antropogénny kalcit vyseparovaný v roku 2013 a rádiouhlíkom (AMS) boli datované tri frakcie $\mathrm{CO}_{2}$ (Folk-Valastro 1976, 205; Ringbom et al. 2014, 620).

\footnotetext{
3 Napríklad na južnej stene predrománskej lode, asi $1 \mathrm{~m}$ od vít’azného oblúka, vo výške ca $80 \mathrm{~cm}$ nad podlahou sú medzi kameňmi v hrubej vrstve primárnej ložnej prihadzovanej omietke odtlačky palca (asi 6 ks), ktorým sa murár snažil klesajúcu hrubú vrstvu omietky pritlačit' k murivu. Ďalšie takéto odtlačky sú aj na severnej stene predrománskej lode asi $60 \mathrm{~cm}$ vl'avo od kazatel'ne, v línii spodného okraja zachovanej predrománskej mal'by.

4 Podl’a terajších zistení bola najskôr nahodená omietka v hornej časti svätyne a následne na ňu namal'ovali výjavy. Potom (pravdepodobne kvôli lešeniu) natiahli omietku zvislého pásu a na nej namal'ovali hlavy svätcov. Neskôr naniesli omietku v spodnej časti steny a pokryli ju mal'bou lambrekýna (fragment z neho sa zachoval na východnej stene presbytéria). Medzi horným a dolným výjavom bol vynechaný pás muriva bez novej omietky. Tento pás dohodili nakoniec a namal'ovali na ňom hlavy svätcov. V 60. rokoch bol tento technologický pracovný postup mylne interpretovaný ako niekol'konásobné vyrovnávanie nerovností stien pod samotnú predrománsku mal'bu.

5 Pri realizácii predrománskeho maliarskeho programu boli uskutočnené vysprávky stien a zámurovka otvoru na východnej stene presbytéria.
} 


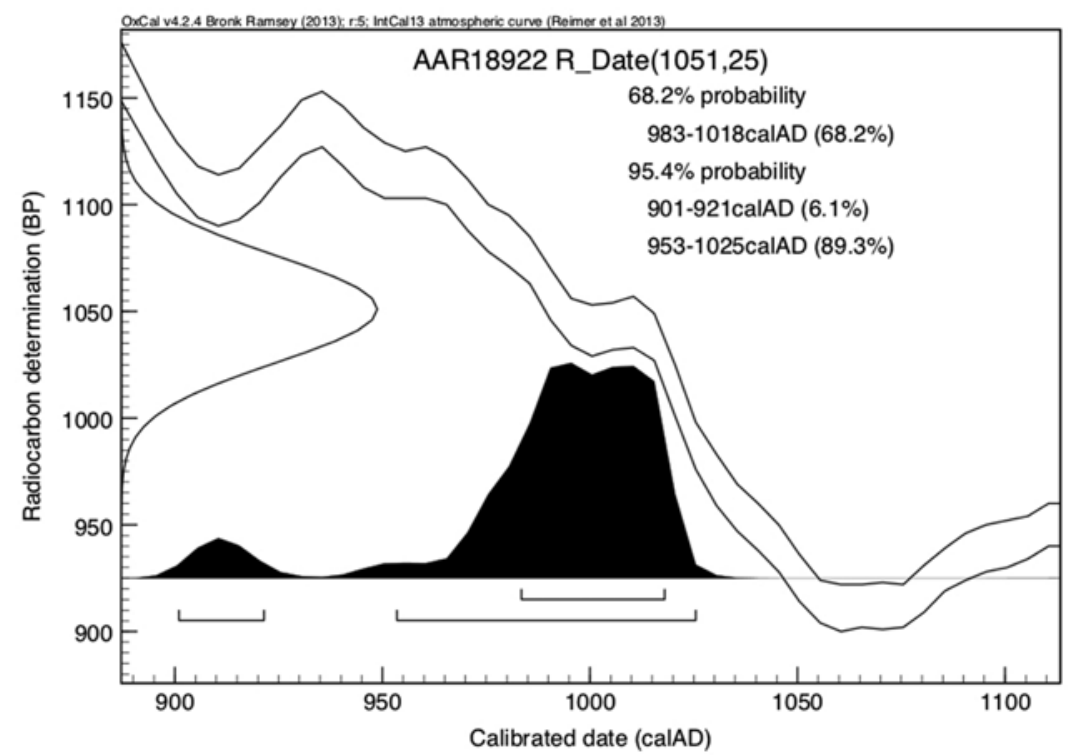

Obr. 10. Datovanie prvej frakcie CO, vzorky KPTM_1 s nulovou apriórnou informáciou. Abb. 10. Datierung der ersten $\mathrm{CO}_{2}$-Fraktion der Probe KPTM_1 mit Null-A-priori-Information.

Vek prvej frakcie (AAR18922: $1051 \pm 25$ BP) sa na konfidenčnej hladine 68,2\% nachádza v intervale 983-1018 calAD; na konfidenčnej hladine 95,4\% je vzorka datovaná do intervalu 901-921 calAD (6,1\%) alebo 953-1025 calAD (89,3\%, obr. 10). Konvenčný ${ }^{14} \mathrm{C}$ vek druhej a tretej frakcie $\mathrm{CO}_{2}$ potvrdzujú, že dátum pre prvú frakciu je kredibilný a omietka KPTM_1 tuhla $\mathrm{v}$ niektorom $\mathrm{z}$ uvedených disjunktných intervalov.

Vzhl'adom na rôzne možnosti interpretácie stratigrafie vzorky KPTM_1 sme v roku 2014 odobrali na inom mieste interiéru kostola d'alšie vzorky z masy omietky, ktorá je jednoznačne stratigraficky charakterizovaná ako omietka nesúca predrománsku mal'bu. Ide o nezuhol'natené rastlinné makrozvyšky, ktoré môžu reprezentovat' $\mathrm{C}_{4}$ rastliny a spôsobit' posun konvenčného ${ }^{14} \mathrm{C}$ veku. Preto skúmame $\delta{ }^{13} \mathrm{C}$ týchto vzoriek pomerovou izotopovou spektrometriou (IRMS). Predbežné zistenie, že predrománska mal'ba mohla vzniknút' v druhej polovici 10. až prvej štvrtine 11. storočia teda overujeme novými, zatial' neukončenými meraniami.

Vzorka KPTM_2 bola spracovávaná rovnako ako KPTM_1 v rokoch 2013 a 2014. Pre prvú $\mathrm{z}$ troch frakcií $\mathrm{CO}_{2}$ bola nameraná (AMS) hodnota konvenčného ${ }^{14} \mathrm{C}$ veku AAR18923:1112 \pm $25 \mathrm{BP}$; táto hodnota je verifikovaná meraniami pre druhú a tretiu frakciu. Tuhnutie omietky KPTM_2 prebehlo na konfidenčnej hladine 68,2\% niekedy v priebehu intervalov 895-928 alebo 941-974 calAD; na konfidenčnej hladine $95,4 \%$ ide o interval $885-990$ calAD (obr. 11).

\section{Datovanie omietok KPTM_1 a KPTM_2 so zohl'adnením ich možných časových vż'ahov}

Ako sme uviedli vyššie, interpretácia stratigrafickej pozície omietky KPTM_1 nie je jednoznačná. Ak vezmeme do úvahy, že v princípe môže íst': 1) o primárnu omietku najstaršieho predrománskeho kostola alebo 2) o mladšiu vysprávku, môžeme vytvorit' dve alternatívy vzájomného časového vzt’ahu vzniku omietok KPTM_1 a KPTM_2. Prvou alternatívou je, že vek ich vzniku je rovnaký a tuhli súčasne. Druhou alternatívou je, že KPTM_1 je mladšia ako KPTM_2, ako to pripúštajú závery najnovšieho reštaurátorského výskumu. Uvedené alterna- 


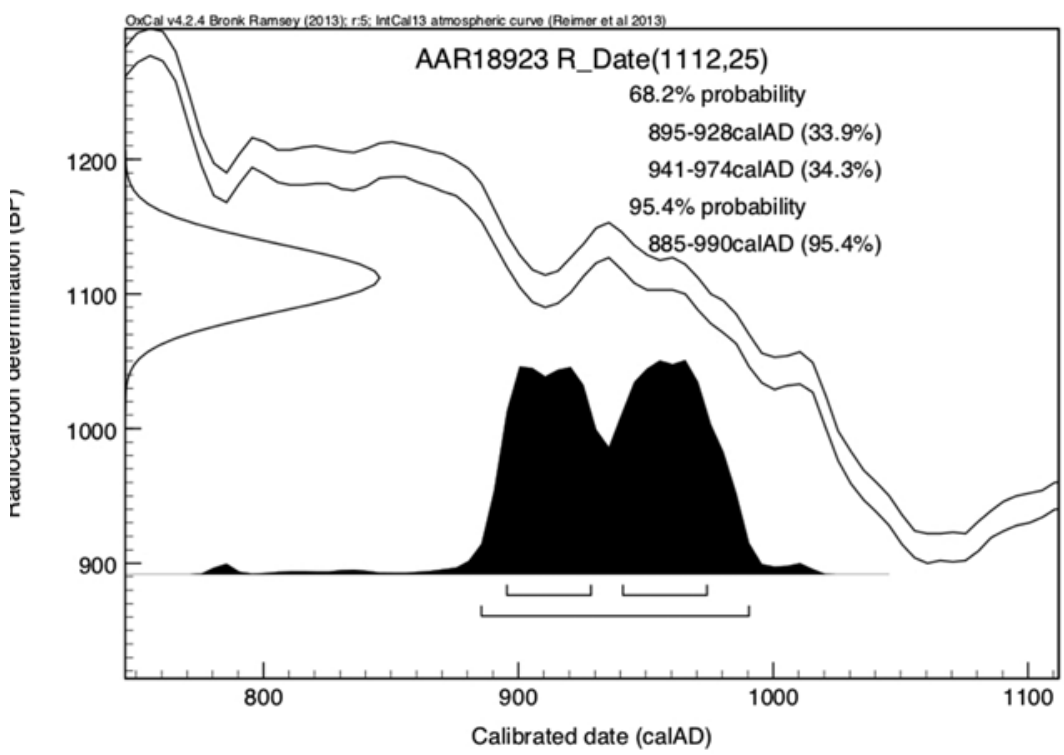

Obr. 11. Datovanie prvej frakcie CO, vzorky KPTM 2 s nulovou apriórnou informáciou.

Abb. 11. Datierung der ersten $\mathrm{CO}_{2}$-Fraktion der Probe KPTM_2 mit Null-A-priori-Information.

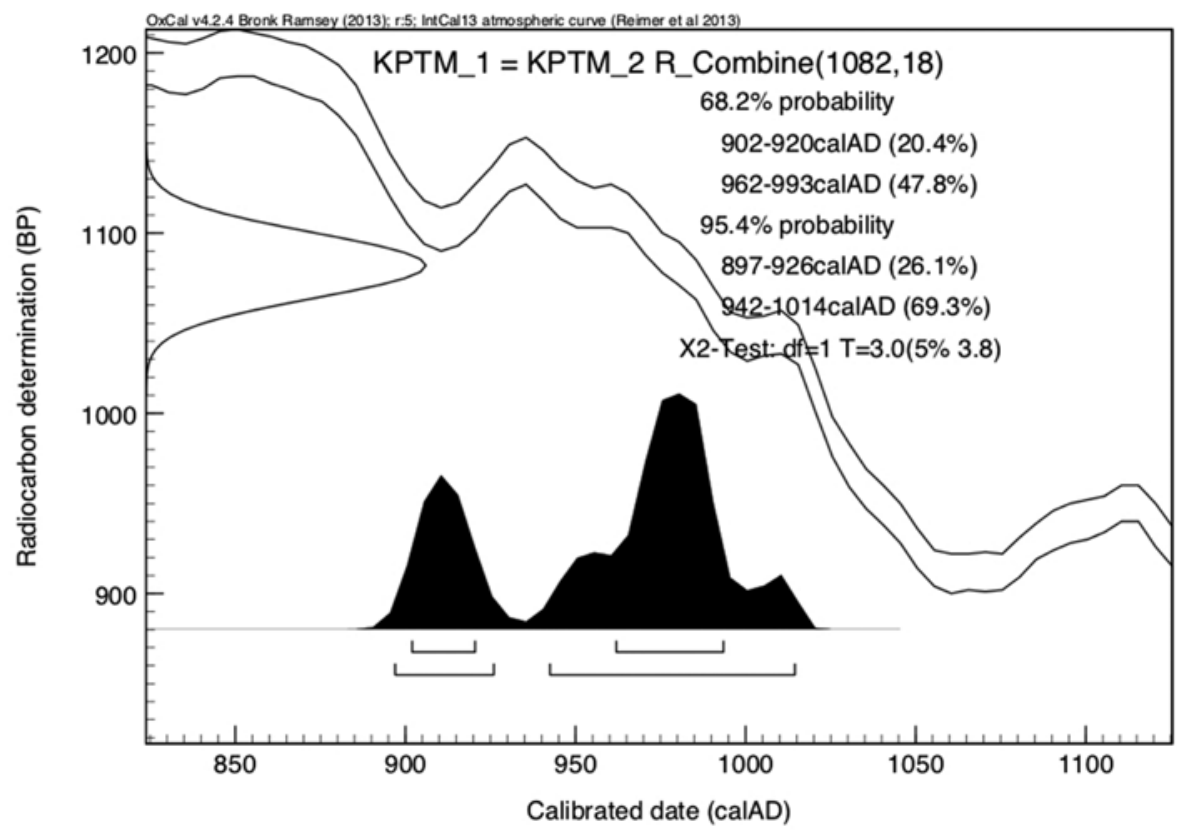

Obr. 12. Datovanie omietok KPTM_1 a KPTM_2. Ak tuhli obidve omietky naraz a reprezentujú jednu udalost', výsledkom sú dve alternatívy datovania.

Abb. 12. Datierung der Putze KPTM 1 und KPTM_2. Wenn beide Putze gleichzeitig abgebunden haben und ein Ereignis repräsentieren, ergeben sich zwei alternative Datierungen. 


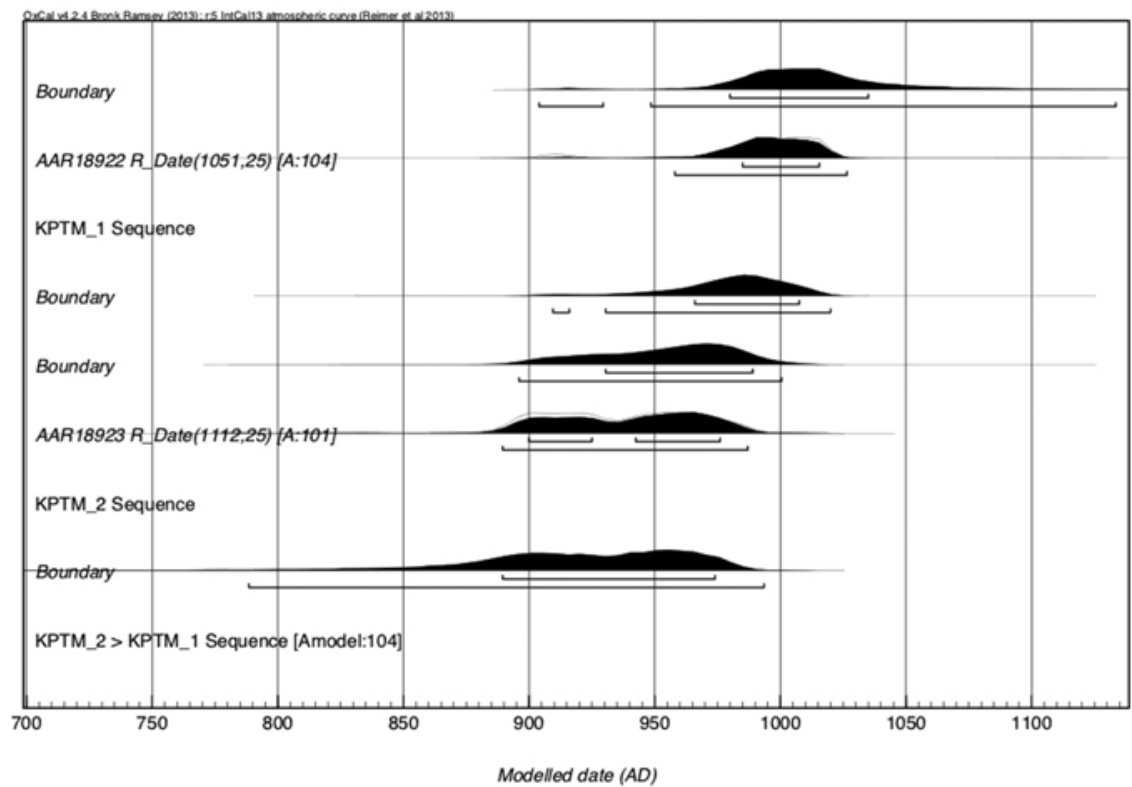

Obr. 13. Kalibrácia hodnôt konvenčného ${ }^{14} \mathrm{C}$ veku pre omietky KPTM_1 a KPTM_2 riadená vzt'ahom, že KPTM_2 je staršia ako KPTM_1 a že doba ich tuhnutia predstavuje dve rôzne neprekrývajúce sa stavebné udalosti. Vyznačené sú intervaly pre konfidenčné hladiny $68,2 \%$ (horné úsečky) a $95,4 \%$ (dolné úsečky).

Abb. 13. Kalibrierung der Werte des konventionellen ${ }^{14}$ C-Alters für die Putze KPTM_1 und KPTM_2. Sie wird gesteuert durch die Beziehung, dass KPTM_2 älter ist als KPTM_1 und dass ihre Abbindezeit zwei verschiedene, sich nicht überlagernde Bauereignisse darstellen. Die Intervalle sind mit einem Konfidenzniveau von 68,2 \% (obere Linien) und 95,4 \% (untere Linien) gekennzeichnet.

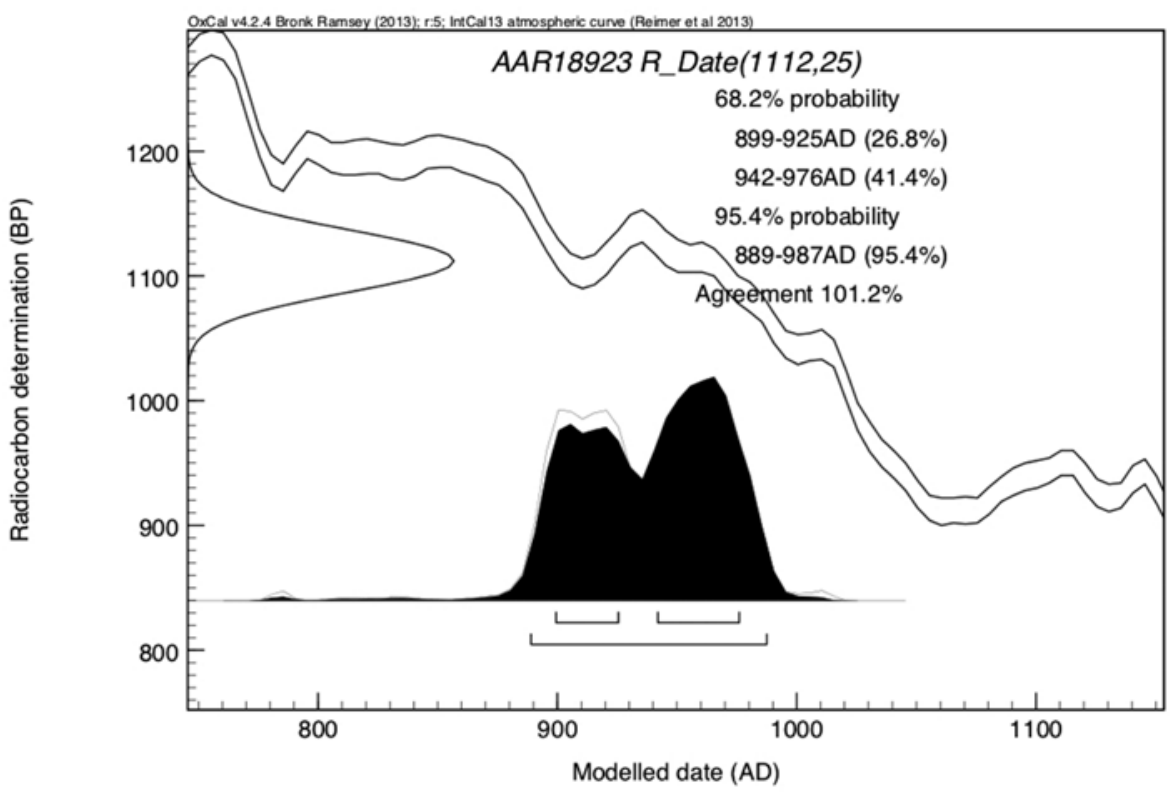

Obr. 14. Datovanie omietky KPTM 2 v prípade, že je staršia ako omietka KPTM 1 (detail z obr. 13).

Abb. 14. Datierung von Putz KPTM_2 für den Fall, dass er älter als Putz KPTM_1 ist (Detail von Abb. 13). 


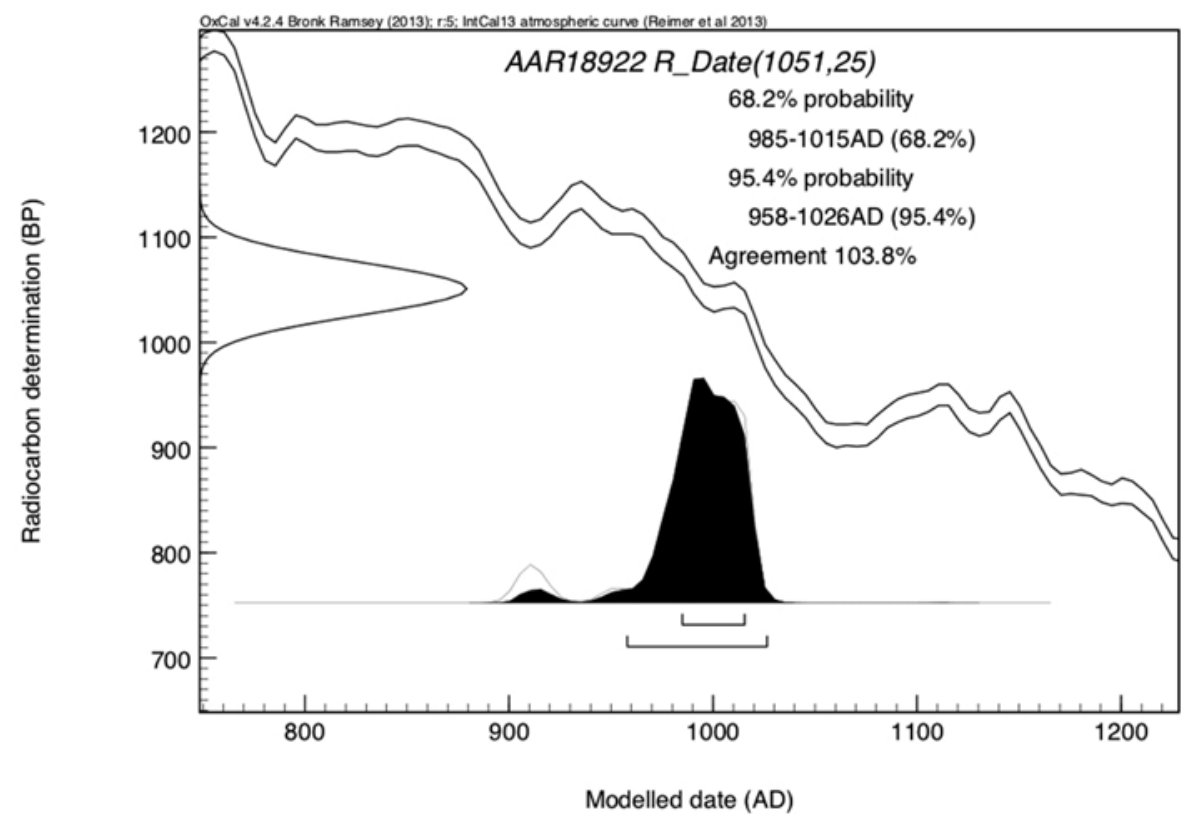

Obr. 15. Datovanie omietky KPTM_1 v prípade, že je mladšia ako omietka KPTM_2 (detail z obr. 13).

Abb. 15. Datierung von Putz KPTM_1 für den Fall, dass er jünger als Putz KPTM_2 ist (Detail von Abb. 13).

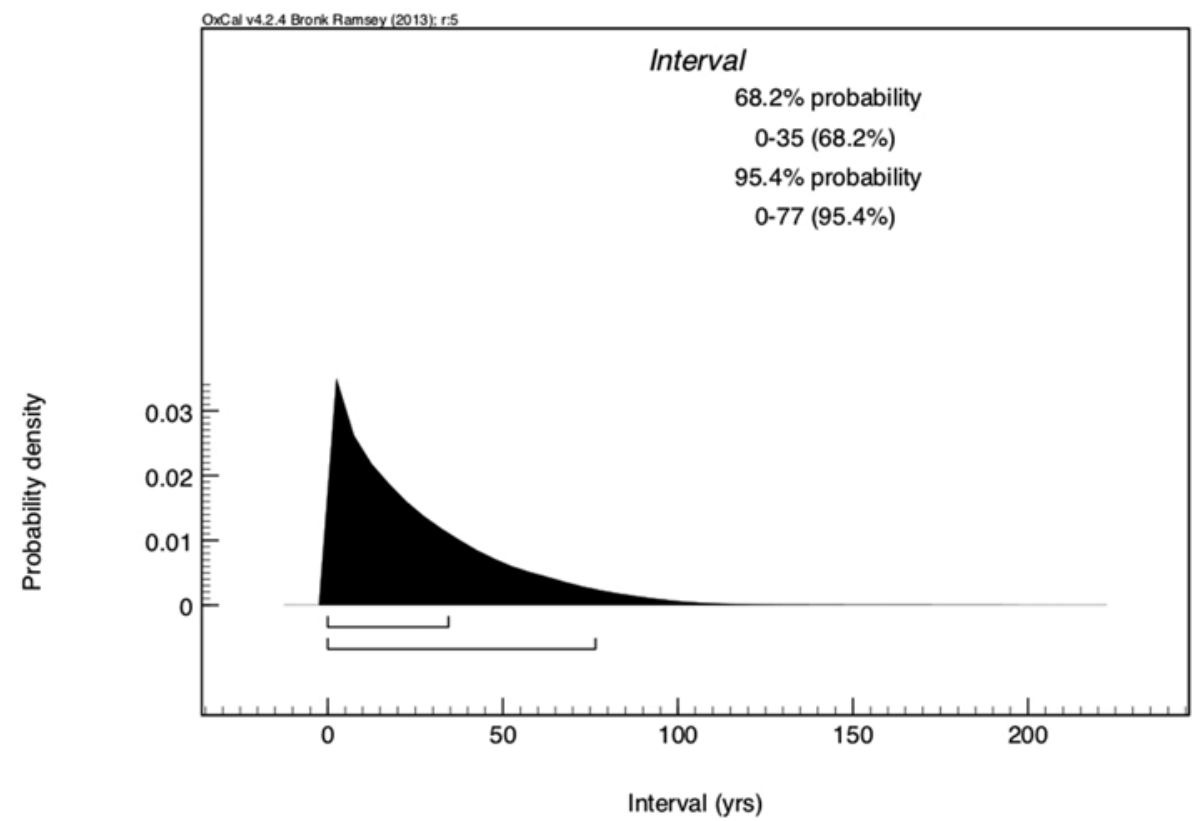

Obr. 16. Časová medzera medzi oboma udalost’ami (tuhnutie omietok KPTM_1 a KPTM_2) vypočítaná na základe riadenej kalibrácie na obr. 13. Mohla byt' široká od niekol'ko po niekol'ko desiatok rokov.

Abb. 16. Zwischen beiden Ereignissen (Abbinden der Putze KPTM_1 und KPTM_2) liegende und auf Grundlage der gesteuerten Kalibrierung in Abb. 13 berechnete Zeitspanne. Sie kann einige Jahre bis zu einigen Jahrzehnten betragen. 
tívy môžeme skúmat' s ciel'om zistit', ktorá z nich je z hl'adiska nameraných ${ }^{14} \mathrm{C}$ dát obhájitel'ná (obr. 10, 11, 12, 13).

Ak omietky KPTM_1 a KPTM_2 predstavujú jednu stavebnú udalost' a stuhli naraz, stalo sa tak v jednom z dvoch disjunktných intervalov, teda $v$ závere 9 . až počiatku 10. storočia alebo v druhej polovici 10. až na počiatku 11. storočia (obr. 12).

Ak omietky predstavujú dve stavebné udalosti a KPTM_2 je staršia ako KPTM_1,je medzi nimi interval, ktorý trval od niekol'ko po niekol'ko desiatok (maximálne 77) rokov; výsledky na konfidenčnej hladine 68,2\% ukazujú, že mladšia omietka stuhla v intervale 985-1015 calAD a staršia v intervale 899-925 alebo 942-976 cal AD (obr. 13, 14, 15).

\section{Datovanie lešenárskej konzoly KPT_3 vo východnom štíte lode}

Druhým dreveným stavebným prvkom, ktorý sme datovali rádiouhlíkom, bola dubová (Quercus sp.) lešenárska gul'atina (KPT_3), odobratá z východného štítu predrománskej lode počas architektonicko-historického výskumu v roku 2010 (Barta-Bóna 2011, 101). Na rozdiel od KPT_1 bola konzola KPT_3 vel'mi silne poškodená drevokazným hmyzom, čo spôsobila skutočnost', že nebola prekrytá omietkou. Po dôkladnom mechanickom vyčistení tejto 22 rokov dlhej sekvencie letokruhov boli uskutočnené dve ${ }^{14} \mathrm{C}$ merania (AMS) dvoch samostatných vzoriek (11 rokov) s následnou pozíciou (KPT_3_1: BETA-291860: $840 \pm 30$ BP; KPT_3_2: BETA-

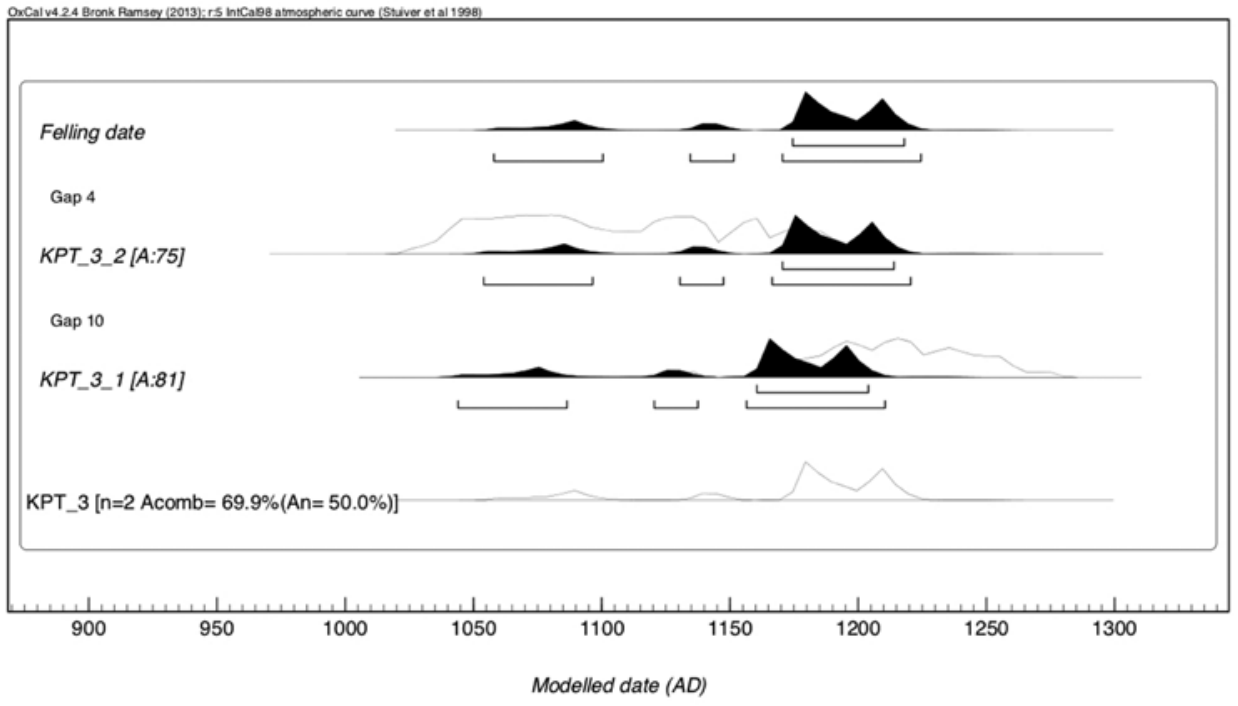

Obr. 17. Kalibrácia ${ }^{14} \mathrm{C}$ dát $\mathrm{z}$ dvoch vzoriek lešenárskej konzoly KPT_3 s najväčšou denzitou pravdepodobnosti v poslednej tretine 12. až prvej štvrtine 13. storočia. Vyznačené sú intervaly na konfidenčných hladinách $68,2 \%$ a $95,4 \%$.

Abb. 17. Kalibrierung der ${ }^{14} \mathrm{C}$-Daten der zwei Proben von der Gerüstkonsole KPT_3 mit höchster Wahrscheinlichkeitsdichte im letzten Drittel des 12. bis zum ersten Viertel des 13. Jahrhunderts. Die Intervalle sind mit einem Konfidenzniveau von $68,2 \%$ und $95,4 \%$ gekennzeichnet.

291861: $910 \pm 30$ BP). Vzhl’adom na dížku doby vzniku signálu vo vzorkách sme na kalibráciu nameraných hodnôt ${ }^{14} \mathrm{C}$ veku použili dekadickú kalibračnú krivku IntCa198 (Stuiver et al. 1998).

Výsledok kalibrácie ${ }^{14} \mathrm{C}$ dát (D_Sequence, Bronk Ramsey et al. 2001; IntCa198, Stuiver et al. 1998) ukazuje, že najvyššia denzita pravdepodobnosti kalendárneho dáta pre výrub gulatiny je na konfidenčnej hladine $95,4 \%$ v intervale $1170-1224$ calAD $(73,8 \%)$; staršie intervaly na konfidenčnej hladine $95,4 \%$ majú nižšiu denzitu pravdepodobnosti a zaberajú rozpätie $1058-1100$ calAD $(14,7 \%)$ a $1134-1151$ calAD (6,9\%; obr. 17). Na konfidenčnej hladine $68,2 \%$ 
je výrub datovaný do intervalu 1174-1218 calAD. Nakol'ko lešenárska gul'atina tvorila primárnu konštrukčnú súčast' najstaršieho zachovaného kamenného muriva štítu, možno výstavbu štítu na základe gul'atiny datovat' do priebehu intervalu 1170-1224 calAD a jeho vznik tak zaradit' $\mathrm{k}$ jednej z neskorších prestavieb predrománskeho kostola. ${ }^{6}$

\section{Záver a diskusia}

Na základe predloženej evidencie je možné vyslovit’ predbežný záver, že kostol bol postavený koncom 9. až v prvej tretine 10. storočia. Nasvedčujú tomu dva priame a jeden nepriamy argument. Prvým priamym argumentom je datovanie najmladšieho možného dátumu pre výrub stromu pre lešenársku konzolu KPT_1 najneskôr do roku 919 calAD. Vzhl'adom na zachovanie povrchu polgul'atiny KPT_1 predpokladáme, že počet nezachovaných letokruhov jadrového dreva je nulový alebo blízky nule. Ak by sme aj v rámci diskusie uvažovali o tom, že nebol nulový, nie je realistické uvažovat' o počte vyššom ako 10 . V takom prípade by bola najneskoršia možná alternatíva výrubu datovaná rokom 929 calAD.

Druhým priamym argumentom je skutočnost', že nech je medzi omietkami KPTM_2 a KPTM_1 akýkol'vek vztah odvoditel'ný zo zistení reštaurátorského výskumu 2012-2013 (KPTM_2 > KPTM_1 alebo KPTM_1=KPTM_2), výsledkom výpočtov sú vždy dva intervaly alebo interval s vysokou denzitou pravdepodobnosti na dvoch miestach. Staršie obdobie zaberá záver 9. až prvú štvrtinu 10. storočia, mladšie zaberá druhú polovicu 10. až začiatok 11. storočia (obr. 12-15). Ak obe omietky predstavujú jedinú udalost' a KPTM_2 tuhla súčasne s KPTM_1 (prvý možný záver reštaurátorského výskumu), stalo sa tak niekedy v intervale 897-926 alebo 942-1014 calAD (konfidenčná hladina 95,4\%; obr. 12). Výsledok kalibrácie ${ }^{14} \mathrm{C}$ dát, ktorú sme riadili druhým z dvoch možných záverov reštaurátorského výskumu, teda, že KPTM_2 je staršia ako KPTM_1, túto alternatívu pripúšta tiež (obr. 13). Mladšia omietka KPTM_1 by v takomto prípade mohla stuhnút' niekedy v intervale 985-1015 calAD (konfidenčná hladina 68,2\%; obr. 15), staršia omietka KPTM_2 v intervale 899-925 alebo 942-976 calAD (konfidenčná hladina $68,2 \%$; obr. 14). Časová medzera medzi oboma udalost’ami by trvala najviac 77 rokov (obr. 16).

Za podstatnú pre naše závery považujeme skutočnost', že kalibrovaný dátum pre omietku KPTM_2 prináša alternatívu jej tuhnutia v závere 9. až prvej štvrtine 10. storočia, rovnako ako od nej argumentačne nezávislé datovanie lešenárskej konzoly KPT_1. Takéto výsledky predstavujú zbiehavé indície. Domnievame sa, že datovanie lešenárskej konzoly KPT_1 oprávňuje vnímat' staršie obdobie s vysokou denzitou pravdepodobnosti pre omietku KPTM_2 (obr. 11, 14) ako interval skutočne obsahujúci dátum, kedy stuhla, a nie ako interval, ktorý je artefaktom kalibračnej krivky.

Tretím, nepriamym argumentom pre datovanie výstavby kostola tak, ako to indikujú KPT_1 a KPTM_2, je obdobie rastu neznámych letokruhov jadrového dreva paliva použitého pri výrobe vápna, ktorého zvyšky obsahovala primárna najstaršia malta; dátum rastu týchto zuhol'natených letokruhov predchádza rok 863 calAD, pričom najvyššia denzita pravdepodobnosti vypín̆a obdobie pred rokom 778 calAD (obr. 8). Predpokladáme, že ak by kostol postavili začiatkom 11. storočia, najvyššia denzita pravdepodobnosti by zaberala plateau v 9. storočí alebo neskoršie obdobie, čím by implikovala rubný vek paliva 200 a menej rokov. Táto úvaha sa odvíja od predpokladu, že počas (vel'komoravského) mocenského rozmachu je reálne počítat' na území Nitrianskeho kniežatstva s vysokou spotrebou kvalitného stavebného a palivového dreva, čím mohli populácie dubov utrpiet' a na začiatku 11. storočia nemuseli byt' už v dostupnejších polohách k dispozícii stromy s vysokým vekom.

6 K určeniu primárnosti štítu kostolnej lode dospeli L. Šášky $(1968,83)$ i J. Maříková-Kubková (2011, 97: pozn. 38). Pre rovnaké závery sa aj počas architektonicko-historického výskumu M. Bónu v roku 2010 prihovárala zistená zhodnost' stavebného materiálu štítu i obvodových múrov predrománskeho kostola. Avšak zároveň si s tým protirečil zistený nesúlad medzi uhl'adenejšou povrchovou úpravou primárnej interiérovej omietky štítu a strohejšie zahládzanou úpravou primárnej interiérovej omietky v presbytériu (Bóna 2010, 114-115). Tento nesúlad sa nakoniec objasnil potvrdením mladšieho pôvodu štítu. 
Na základe predložených ${ }^{14} \mathrm{C}$ dát a ich kalibrácie zohladňujúcej stratigrafické súvislosti analyzovaných vzoriek, resp. ich vzt’ahy v reálnom čase, môžeme povedat' nasledovné: nateraz sa domnievame, že Kostol Sv. Juraja v Kostol'anoch pod Tribečom bol postavený najneskôr v prvej štvrtine 10. storočia a že v súvislosti s realizáciou jeho mladšej nástennej výmal'by bol niekedy v priebehu druhej polovice 10 . až počiatku 11. storočia u/opravovaný. Tento záver podlieha verifikácii na základe prebiehajúcich meraní ${ }^{14} \mathrm{C}$ novoodobratých vzoriek a vzorky omietky KPTM_3 a ich štatistického spracovania.

Táto práca bola podporená Agentúrou na podporu výskumu a vývoja na základe Zmluvy č. APVV-0598-10. IRMS merania stabilných izotopov boli podporené prostriedkami z grantu VEGA 1/0964/13.

\section{Pramene a literatúra}

BAKOŠ, J., 1968: Genéza nástenných malieb v Kostolanoch pod Tribečom, Vlastivedný časopis XVII, č. 4, 178-181.

BARTA, P., 2008: Studies on absolute chronology of the Bronze Age in East-Central Europe: methods and applications. Vol. I, II., dizertačná práca, Archeologický ústav SAV, Nitra.

- 2008a: K absolútnej chronológii doby bronzovej vo východnej strednej Európe: metódy a aplikácie. Bratislava.

BARTA, P.-BÓNA, M., 2010: Chronometrické datovanie muriva Kostola sv. Juraja v Kostolanoch pod Tribečom: prvé výsledky, Monumentorum Tutela - Ochrana pamiatok 22, 54-59.

- 2011: Chronometric Dating of St. George's Church in Kostolany pod Tribečom, West Slovakia. In: Program and Abstracts, 6th International Symposium Radiocarbon and Archaeology, 10-15 April 2011, Pafos, Cyprus, 101.

BAXA, P.-BISTÁK, P., 2009: Prvé výsledky revízneho archeologického výskumu cintorína pri Kostole sv. Juraja v Kostolanoch pod Tribečom, Monumentorum Tutela - Ochrana pamiatok 21, $53-64$.

BAXA, P.-MAŘÍKOVÁ-KUBKOVÁ, J., 2010: Die älteste Phase der Kirche St. Georg in Kostolany pod Tríbečom. In: Frühmittelalterliche Kirchen als archäologische und historische Quelle. Internationale Tagungen in Mikulčice VIII (Poláček, L.-Mař́́ková-Kubková, J., edd.), 149-160. Brno.

- 2011: Objev nejstarší fáze kostela sv. Jiř́i v Kostol’anech pod Tribečom, Ranostredoveká sakrálna architektúra Nitrianskeho kraja: Zborník zo seminára a katalóg ku výstave, 89-101. Nitra.

- 2013: Kapitola VI, čast' Pamiatky. In: Baxa, P. a kolektív, Kostolany pod Tribečom. Monografia obce, 195-215. Kostol'any pod Tribečom.

BÓNA, M., 2010: Kostol’any pod Tribečom - Rímskokatolícky Kostol sv. Juraja. Umelecko-historický a architektonicko-historický výskum 2000-2001 a 2009-2010. Výskumná dokumentácia 2010, ulož. v Archíve KPÚ v Nitre a Archíve R. k. cirkvi - farnost' Ladice.

- 2012: Kostolany pod Tribečom, Kostol sv. Juraja - umeleckohistorický a architektonicko-historický výskum. In: Ročenka pamiatkových výskumov 2010 (Orosová, M., ed.), 81-83. Bratislava (CD-Rom).

- 2014: Výsledky umelecko-historického a architektonicko-historického výskumu r. k. Kostola sv. Juraja v Kostolanoch pod Tribečom, Zborník FF UK - Musaica XXVIII, 127-161.

BRONK RAMSEY, C., 2009: Bayesian analysis of radiocarbon dates, Radiocarbon 51, 337-360.

BRONK RAMSEY, C. et al., 2001: Bronk Ramsey, C.-Van Der Plicht, J.-Weninger, B., 'Wiggle matching' radiocarbon dates, Radiocarbon 43, 381-389.

DVOŘÁKOVÁ, V.-KRÁSA, J., 1961: Zpráva o průzkumu slovenských středověkých nástěnných maleb konaném v záŕí 1960, Umění IX, 197-201.

FODOR, P., 1968: Nástenné mal'by v Kostol’anoch pod Tribečom z hladiska techniky mal'by, Monumentorum Tutela - Ochrana pamiatok 2, 97-114.

FOLK, R. L.-VALASTRO, S., 1976: Successful Technique for Dating of Lime Mortar by Carbon-14, Journal of Field Archaeology 3, 203-208. 
GERÁT, I., 2007: Stredovek. In: Kolektív autorov, Umenie na Slovensku. Stručné dejiny obrazov, 32-73. Bratislava.

HABOVŠTIAK, A., 1965: Predbežná správa o výsledkoch archeologického výskumu v Kostolanoch pod Tribečom, Ochranca prírody a pamiatok V, č. 7-8, 5-6.

- 1966: Kostolany pod Tribečom. Správa o zistovacom a záchrannom výskume realizovanom v období od 28. 8. do 30. 10. 1964 a od 1. 6. do 12. 7. 1965, nálezová správa č. 3127/1966, ulož. v Archíve AÚ SAV Nitra.

- 1968: Archeologický výskum v Kostol’anoch pod Tribečom, Monumentorum Tutela - Ochrana pamiatok 2, 43-73.

- 1978: Kostol’any pod Tribečom, okres Nitra. In: Významné slovanské náleziská na Slovensku (Chropovský, B., ed.), 105-108. Bratislava.

- 1985: Stredoveká dedina na Slovensku. Bratislava.

HEUSSNER, U., 1999: Wieviel fehlt? - Ein Beitrag zur Genauigkeit von dendrochronologischen Datierungen. In: Den Bogen spannen... Festschrift für Bernhard Gramsch zum 65. Geburtstag. Beiträge zur Beiträge zur Ur- und Frühgeschichte Frühgeschichte Mitteleuropas 20 (Cziesla, E.Kersting, T.-Pratsch, S., edd.), 523-525. Weissbach.

KRÁSA, J., 1968: Nástěnné malby v kostele sv. Jiří v Kostol’anoch pod Tribečom, Monumentorum Tutela - Ochrana pamiatok 2, 115-127.

KRESÁNEK, P., 2009: Slovensko - ilustrovaná encyklopédia pamiatok. Bratislava.

MAŘÍKOVÁ-KUBKOVÁ, J., 2011: Nové směry ve výzkumu raně středověké architektury. In: Co můj kostel dnes má, nemůže kníže odníti. Věnováno Petru Sommerovi k životnímu jubileu (Doležalová, E.-Meduna, P., edd.), 85-97. Praha.

MAŘÍKOVÁ-KUBKOVÁ, J.-BERGER, T., 2009: První stavební fáze kostela sv. Juraja v Kostolanech pod Tribečom, Monumentorum Tutela - Ochrana pamiatok 21, 97-152.

REIMER, P. J. et al., 2013: Reimer, P. J.-Bard, E.-Bayliss, A.-Beck, J. W.-Blackwell, P. G.-Bronk Ramsey, C.-Grootes, P. M.-Guilderson, T. P.-Haflidason, H.-Hajdas, I.-Hatte, C.-Heaton, T. J.Hoffmann, D. L.-Hogg, A. G.-Hughen, K. A.-Kaiser, K. F.-Kromer, B.-Manning, S. W.-Niu, M.Reimer, R. W.-Richards, D. A.-Scott, E. M.-Southon, J. R.-Staff, R. A.-Turney, C. S. M.van der Plicht, J., IntCal13 and Marine13 radiocarbon age calibration curves 0-50,000 years cal BP, Radiocarbon 55, 1869-1887. DOI: 10.2458/azu_js_rc.55.16947

RINGBOM, A. et al., 2014: Ringbom, A.-Lindroos, A.-Heinemier, J.-Sonck-Koota, P., 19 years of mortar dating: learning from experience, Radiocarbon 56, 619-635. DOI: 10.2458/56.17469

RUTTKAY, A., 2011: Najstaršie sakrálne stavby na území Nitrianskeho samosprávneho kraja vo svetle archeologických výskumov. In: Ranostredoveká sakrálna architektúra Nitrianskeho kraja. Zborník zo seminára a katalóg ku výstave (Valeková, A., ed.), 39-58. Nitra.

STUIVER, M. et al., 1998: Stuiver, M.-Reimer, P. J.-Bard, E.-Beck, J. W.-Burr, G. S.-Hughen, K. A.Kromer, B.-Mccormac, G.-Van Der Plicht, J.-Spurk, M., INTCAL98 radiocarbon age calibration, 24,000-0 cal BP, Radiocarbon, 40, 1041-1083.

ŠÁŠKY, L., 1965: Kostol v Kostol’anoch pod Tribečom, Ochranca prírody a pamiatok V, č. 7-8, 2-3.

- 1968: Predrománsky kostol v Kostolanoch pod Tribečom, Monumentorum Tutela - Ochrana pamiatok 2, 79-95.

\section{Zusammenfassung}

\section{Die chronometrische Untersuchung der Gemäuer der St. Georgskirche in Kostol'any pod Tribečom}

Der vorliegende Beitrag stellt die vorläufigen Ergebnisse der in den Jahren 2010-2014 durchgeführten ${ }^{14} \mathrm{C}$-Datierungen der oberirdischen Gemäuer der St. Georgskirche in Kostol'any pod Tribečom vor. Ziel unserer Bemühungen war eine Datierung der ältesten Bauphase der vorromanischen Kirche. Aus Gründen der gegenseitigen Datenkontrolle haben wir auch solche Proben ausgewählt, die zur Bauzeit der Kirche eine qualitativ unterschiedliche Beziehung haben und deren Entstehungsmechanismus verschieden ist. Bei zwei Bauholzproben, drei Kalk- 
putzproben (anthropogener Calcit) und einer verkohlten Holzprobe im Putz wurden jeweils $15{ }^{14} \mathrm{C}$-Daten gemessen, von denen 10 im vorliegenden Beitrag präsentiert werden.

Träger eines absoluten Datums für den Bau der Kirche im Sinne eines terminus a quo ist die halbrunde Gerüstkonsole KPT_1 in primärer Lage im ältesten Gemäuer an der Südfassade, die aus dem Holz einer Eiche besteht, deren Fälldatum wir ermittelt haben. Analog dazu wurde auch der älteste primäre Außenputz KPTM_3 an der Nordfassade des Kirchenschiffs als Träger eines terminus a quo für den Bau der Kirche ausgewählt. Von dem vorromanischen Innenputz wurden zwei Proben entnommen. Da die primäre Baumasse der Kirche bereits früh baulichen Veränderungen unterworfen war, wurden von uns sowohl in der Nordwand (KPTM_1) als auch in der Südwand (KPTM_2) des Chorraums Proben entnommen, um die Wahrscheinlichkeit zu erhöhen, dass zumindest eine der Proben von der ältesten Behandlung der Wände stammt (terminus a quo für den Bau). Als Träger eines terminus post quem für den Bau der Kirche haben wir ein verkohltes Holzstück (Eiche) gewählt, das von uns als Überbleibsel des zum Kalklöschen verwendeten Brennstoffs interpretiert wird. Dieses Holzkohlefragment haben wir vom ältesten Primärputz im Bereich des Mittelfenster an der Südfassade des Kirchenschiffs präpariert. Die zweite von uns datierte Gerüstkonsole KPT_3 stammt aus dem Ostgiebel des Kirchenschiffs und stellt ein Eichenrundholz aus einem Mauerwerk dar, das gegenüber dem Gemäuer des Kirchenschiffs einer anderen Oberflächenbehandlung unterworfen war, obwohl es aus dem gleichen Baustoff besteht (siehe Anm. 5).

Alle ${ }^{14} \mathrm{C}$-Daten wurden auf Grundlage der Beziehung zwischen den datierten Proben in Echtzeit kalibriert (OXCal). Für die chronologischen Modelle mit mindestens einer Probe, in welcher das Signal 5 Jahre oder kürzer ausmachte (KPT_1, KPTC_1, KPTM_1 bis 3), haben wir die Datenbank IntCal13 verwendet, für Proben mit einem Signal von 11 Jahren (KPT_3) dann IntCal98.

Die argumentatorisch voneinander abweichenden und unabhängigen Datierungen der Fällzeit des Baumes der Gerüstkonsole KPT_1 und des Putzes KPTM_2 ergaben ein übereinstimmendes Ergebnis. Die Fällung des Baumes für KPT_2 erfolgte der vorgeschlagenen chronologischen Modellierung nach spätestens Ende des 9. Jahrhunderts bis zum ersten Viertel des 10. Jahrhunderts calAD (Abb. 7), und einer der zwei Bereiche mit hoher Wahrscheinlichkeitsdichte für KPTM_2 wird ebenso datiert (Abb. 11, 13). Die Holzkohle KPTC_1, d.h. der Brennstoffrest vom Kalklöschen, stammt vom ältesten Primärputz. Es ist offensichtlich, das das Wachstum seiner Jahresringe vor der Abbindezeit des ältesten Primärputzes erfolgte. Das Datum für KPTC_1, dessen höchste Wahrscheinlichkeitsdichte im 7. und 8. Jahrhundert calAD liegt, hat diese Annahme bestätigt. Putz KPTM_1 ist stratigraphisch nicht eindeutig charakterisierbar. Es ist möglich, dass es sich bei ihm nicht um den ältesten Primärputz, sondern um den Trägerputz einer vorromanischen Malerei handelt. In dem Fall würde die Entstehung dieses Putzes in die Zeit zwischen der zweiten Hälfte des 10. bis zum Anfang des 11. Jahrhunderts datiert (Abb. 10, 13). Die Gerüstkonsole aus Eichenrundholz KPT_3 wird unseren Ergebnissen nach in die Zeit zwischen dem Ende des 12. bis zum ersten Viertel des 13. Jahrhunderts datiert (Abb. 17). Die Daten für Putz KPTM_3, dessen Datierung noch nicht abgeschlossen ist, bleiben weiterhin Gegenstand von Analysen.

Anhand der vorgelegten ${ }^{14} \mathrm{C}$-Daten und ihrer die stratigraphischen Zusammenhänge berücksichtigenden Kalibrierung der analysierten Proben, bzw. ihrer jeweiligen Beziehung in Echtzeit, nehmen wir vorerst an, dass die St. Georgskirche in Kostol'any pod Tribečom spätestens im ersten Viertel des 10. Jahrhunderts errichtet und irgendwann im Laufe der zweiten Hälfte des 10. Jahrhunderts bis zum Beginn des 11. Jahrhunderts renoviert oder verändert wurde. Diese Schlussfolgerung muss noch anhand der zur Zeit erfolgenden ${ }^{14} \mathrm{C}-$ Messungen der neu entnommenen Proben und der Putzproben KPTM_3 und ihrer statistischen Auswertung verifiziert werden. 
Die Entstehung der vorliegenden Arbeit wurde von der Agentur zur Förderung von Forschung und Entwicklung gefördert (Vertrag Nr. APVV-0598-10). Die IRMS-Messungen stabiler Isotopen wurden durch Fördermittel der Wissenschaftsförderagentur VEGA 1/0964/13 gefördert.

Mgr. Peter Barta, PhD., Katedra archeológie Filozofickej fakulty Univerzity Komenského v Bratislave, Gondova 2, SK 81499 Bratislava, Slovenská republika, peter.barta@uniba.sk

Ing. arch. Martin Bóna, PhD., ProMonument s.r. o., Štefánikova 14, SK 95301 Zlaté Moravce, Slovenská republika,bona.martin@gmail.com

Mgr. art. Marián Keleši, Oblastný reštaurátorský ateliér Levoča, Nová 55, SK 05401 Levoča, Slovenská republika, ivica.markovicova@gmail.com 
